\title{
Mundos em miniatura: aproximação a alguns aspectos da cartografia portuguesa do Brasil (séculos XVI a XVIII)
}

Joaquim Romero Magalhães ${ }^{1}$

RESUMO: O artigo explora os desafios de "miniaturização" do mundo na cartografia portuguesa do início da época moderna. Chama atenção para o processo de acumulação de experiências e conhecimentos geográficos mobilizados nas representações cartográficas ao longo dos primeiros três séculos de colonização do Brasil.

PALAVRAS-CHAVE: Cartografia Portuguesa. Miniaturização. Colonização inicial do Brasil.

ABSTRACT: This paper discusses the challenges of 'miniaturizing' the world in Portuguese cartography at the dawn of the Modern Age. It draws attention to the process of amassing experience and geographic knowledge, and their deployment in the cartographic representations of Brazil throughout the first three centuries of its colonization.

KEYWORDS: Portuguese cartography. Miniaturization. Early colonization of Brazil.

Ao Almirante Max Justo Guedes
1. Professor Catedrático da Universidade de Coimbra E-mail: <jromero@fe.uc.pt>

Resumir a imensidade do Mundo numa simples folha de papel - ou de papiro ou de pergaminho que seja - é uma tarefa que há milhares de anos desafia os homens. Porque cartografar não é mais do que reduzir os espaços reais para os apreender através de minúsculos desenhos. Pretende-se ver a amplitude do mundo real numa dimensão que os olhos dos humanos possam abarcar. Olhar que nos diga onde estamos e qual o caminho pelo qual queremos caminhar. Mas a dimensão não é o único factor que dificulta a utilização dos mapas. É que também é necessário dominar a linguagem em que estão desenhados.

Para quem não é especialista, a tarefa é muito complicada, pois há que ter presente a chave, a convenção ou o código que permita a interpretação do desenho. E isso não é intuitivo nem imediato. Tem uma história. E há códigos 
2. Cf. Vitorino M. Godinho (1944); Armando Cortesão e TA, Teixeira da Mota (1960); Charles Verlinden (1979); Alfredo Pinheiro Marques (1987); Max Justo Guedes (1997a). perdidos, há traços que não sabemos interpretar, há vestígios de culturas ou de imaginações que se perderam. Não se pode dizer que aqueles que traçaram essas linhas não souberam desenhar. O que se passa é que na nossa forma mentis perdemos os significados desses sinais. Mas os cartógrafos de outros mundos, de outras culturas, de outras civilizações viam o que nós esquecemos - ou nunca soubemos. Porque o tempo do observador é aqui uma coordenada determinante. E, no mesmo nosso tempo, estamos já atrasados pelo que respeita a novas formas e a novos códigos.

Estudar a cartografia não é fácil. Por muitas razões, e não apenas pela falta dos códigos contemporâneos. É também materialmente complicado. As follhas autênticas não estão disponíveis, ou só o estão muito poucas vezes, pelo que há estudar em reproduções, muitas vezes de má qualidade. Que, ainda por cima, só estão disponíveis nas bibliotecas, já que os nossos escritórios não estão preparados para receber atlas e outras publicações de grandes dimensões. Mas há mais. Há mapas que se encontram encaixilhados em estruturas rígidas, e nem sequer foram radiografados para se saber o que ocultam. Procedimentos normais com pinturas antigas não têm sido praticados com os mapas mais preciosos. Assim acontece com o célebre Cantino. Há uma folha de pergaminho colada no espaço brasileiro e nunca foi averiguado o que poderá estar por baixo. E isso podia ser decisivo para se saber mais sobre uma peça fundamental para o estudo da evolução da imagem do Mundo em começos do século XVI.

Tampouco sabemos tudo sobre os mapas que estão nas grandes bibliotecas. Claro que sabemos das preciosidades. Mas para o historiador isso é o que importa menos. Porque há peças que estão por catalogar ou estão incluídas em livros, e que são cadeias indispensáveis para reconstituir o percurso informativo. Porque os mapas não são desenhados sem copiar outros anteriores. Nenhum cartógrafo - salvo os que podemos imaginar encarregados de figurar num espaço virgem - está trabalhando em espaços totalmente desconhecidos e vai a criar alguma coisa também totalmente nova. $\bigcirc$ bom cartógrafo é um bom copista. Limita-se a copiar o já averiguado e a acrescentar o que de novo foi observado. E os que vierem depois farão o mesmo. Pelo que se reconstituem verdadeiras genealogias que indicam as etapas de uma caminhada do saber geográfico. Assim é a disciplina.

Da cartografia portuguesa primitiva, do século XV, são poucos os exemplares: só temos três ${ }^{2}$. O que significa que nos falta muita informação. E os que conhecemos, há sempre que perguntar para que serviria cada um deles. É muito difícil aceitar que alguns dos que temos tenham sido cartas de navegação prática. Podemos imaginar que a bordo das naus e das caravelas a duração dos mapas não podia ser muita. Água, acidentes, pouco cuidado, tudo tenderia para os puir e os rasgar. Não há como imaginar que um mapa fizesse mais de uma viagem. E boa parte dos que hoje possuímos são objectos de luxo e de arte. Para que foram feitos? Por se prescrutá-los pelo lado do emissor, não importa menos considerá-los pelo lado do receptor. A apropriação simbólica do espaço, a sua criação e produção é o que se reproduz no desenho da miniatura. 
O belíssimo Atlas Miller, sabemos que foi uma oferta para o Papa Leão $X$. Não podia servir para navegar. $\bigcirc$ famoso Cantino esteve guardado durante séculos em Ferrara e depois em Modena. $\bigcirc$ mapa-múndi de Martellus está em duas folhas de um livro que nunca esteve num navio - é o resultado de uma investigação teórica e não é uma carta de marear ${ }^{3}$.

A curiosidade ia impondo que se acrescentassem novidades também na cartografia de luxo - não para navegadores mas para reis, senhores e sábios. As novas terras são registadas: é o caso do mapa-mundi de Enricus Martellus Germanicus (1489) que é a primeira tentativa de apresentar a passagem entre dois Oceanos a sul da África. E isso quando só passava, e quando muito, apenas um ano da descoberta de Bartolomeu Dias (1488). Supõe-se que o cartógrafo não viu um mapa com essas informações. Que as recebeu de fontes portuguesas - apesar de uma forte presença de Ptolomeo - e, por isso, disse-se que tem uma raiz luso-ptolomaica. Os mapas de Enricus Martellus foram desenhados na ltália, onde as informações portuguesas cedo chegavam. Informações sobre as novas terras descobertas, que vão sendo difundidas por mapas comprados, mapas oferecidos e mesmo mapas roubados. Para nós são peças soltas de séries que penosamente procuramos ordenar ${ }^{4}$.

Em 22 de Abril de 1500, ao chegar à praia de uma terra nova a que chamaram de Vera Cruz que não se sabia se era ilha ou terra firme -, o físico e cirurgião mestre João Farras escreve ao rei D. Manuel dizendo-lhe que havia uma disputa entre ele e os pilotos da armada de Pedro Álvares Cabral: no Cabo de Boa Esperança se saberia quem dizia verdade, se os pilotos com o mapa, se ele com o mapa e com o estrolabio. E acrescenta: "Quanto senhor al sytyo desta terra mande Vosa Alteza traer un mapamundi que tiene Pero Vaaz Bisagudo e por ay podrra ver Vosa Alteza el sytyo desta terra en pero aquel mapamundi nom certifica esta terra ser habitada o no, es mapamundi antiguo y ally fallera Vosa Alteza escrita tambyen la Myna" ${ }^{\prime \prime}$. Quer isto dizer que, mesmo chegando a uma terra nova, que pela primeira vez naquela viagem se achara, o rei nem mesmo podia, num mapa-mundi - e só o poderia num mapa-mndi -, saber onde é que ficava. Pelos mapa-mundi existentes haveria a possibilidade de achar a resposta que se queria - neste caso. Era uma cartografia, em parte fantástica, como a de Fra Mauro, a de Toscanelli e a de Martim Behaim (às vezes dito Martinho de Boêmia), onde se procurava miniaturizar toda uma imagem da terra, mesmo que fora da realidade estivessem as formas do que se ignorava. Mas não representavam invenções: eram interpretações segundo os paradigmas que se seguiam. "Misturavam-se descrições não-cartográficas com interpretações cartográficas." E iam-se incorporando informações novas, as que recebiam nas suas oficinas estes cosmógrafos. Misturando-se com a tradição e com as teorias e crenças. E respeitando as autoridades antigas, como o sempre presente Ptolomeo - que não é ptolomaico antigo mas uma modernização humanista do pensamento grego tradicional - elaborada século XV. Em alguns casos de dúvida as cores dos desenhos poderiam servir de sinais indicativos. A que iam sendo acrescentadas as novidades que os portugueses e andaluzes traziam das suas andanças a
3. Ver W. G. L. Randles (1995).

4. Ver Teixeira da Mota (1958); e Inácio Guerreiro (1992, 1995, 1997b).

5. Cf. Joaquim Romero Magalhaes e Susana Münch Miranda (1999). 
6. Ver Iaria Luzzana Caraci (2003).

7. Ver Luís de Albuquerque (1977); W. G. L. Randles (1995); e Wilcom E. Washburn (1969).

8. Ver A. Teixeira da Mota (1978).

9. Ver Francisco Morales Padron (1990).

10. Ver Luís de Albuquerque (1977).

11. Ver Fernando Lourenço Fernandes (2003).

12. Ver A. Teixeira da Mota (1978). desvendar o mundo novo. Seguramente que, nesses mapamundi, sempre haveria uma resposta. Diz-se que Fra Mauro é um compêndio de fontes geográficas: nele se incluem as explorações portuguesas em África, a Geografia, de Ptolomeu, as cartas-portulano do Mediterrâneo e narrativas de viagens, como as de Marco Polo e de Nicolo di Conti. Fra Mauro é o que mais tarde se chamará um geógrafo de gabinete - um erudito sem experiência de navegação. Que tem de concatenar a imensa informação que chega a Veneza uma concepção do Mundo que quer apresentar como prova. Nem tudo seria "coisa vista por olho". As observações diretas que pilotos e navegantes podiam fazer registram-se em mapas parciais, como resultado das viagens de descobrimento. Onde se desenhavam mapas para navegação, na linha das cartas-portulanos mediterrânicas concebidas para fins práticos. Só depois se incorporavam na visão global erudita, e sobretudo terrestre, proposta pelos ${ }^{6}$. Assim, o conhecimento do Mundo renovava-se muito devagar. Porque os mapas parciais, nascidos da observação, não procuravam provar nada. Eram os - que pretendiam apresentar uma visão global miniaturizada do Mundo. Só em princípios do século XVI a contaminação do observado se faz sentir vivamente na cartografia de gabinete, de raiz erudita?

$\bigcirc$ peso do antigo não deixa de estar presente. É o que se vê nas primeiras representações do Sul da África, que, apesar de muito corretas, estendem para o leste, para não abandonar totalmente a concepção ptolomaica. Há como que uma resistência à novidade. Eram terras ainda não percorridas pelos navegantes lusos. Ou permaneciam como velhas tradições medievais ${ }^{8}$.

Se mandou vir o - de Pero Vaz Bisagudo, Dom Manuel decerto que terá visto algumas ithas a oeste do Atlântico e decerto que também terá visto a Ásia representada a oeste. E pôde localizar a Terra de Vera Cruz, a 17 graus de latitude Sul. O que implica que o dito - tivesse a graduação indicada. Mas só se veria com alguma aproximação à realidade quando no padrão real fossem desenhadas as linhas que correspondiam às terras que os navegantes de Cabral descobriram, viram e registaram. É o mais provável. Porque esses mapas velhos davam as visões possíveis do mundo desconhecido. Cristóvão Colombo levava um mapa "con muchas islas pintadas" que the servia para discutir a rota que ia escolhendo?. E muitas vezes esses mapas garantiam a existência de terras fantásticas, que não se perdiam com as novidades incorporadas. Não se encontrariam nos lugares onde se esperava, mas havia que aguardar até que desaparecessem em definitivo. A llha de São Brandão persistiu no Atlântico, empurrada para várias posições até 1867 ... 10 Por rotina ou por inadvertência, muitos arcaismos permanecem nas cartas geográficas.

Em 1501, Alberto Cantino, agente de Hércules, duque de Ferrara, veio a Lisboa para obter mapas. Pagou a um anônimo português a cópia do padrão real que se encontrava nos Armazéns reais da Guiné e da Índia, que levou para o seu senhor às escondidas ${ }^{11}$ (Figura 1). É com o nome do espião que hoje se conhece o planisfério de 1502, o chamado mapa de Cantino. É uma obra preciosa. A representação da África - salvo pelo que toca ao Mar Roxo, ainda por bem conhecer na época - é de uma assinalável perfeição ${ }^{12}$. E com isso o 


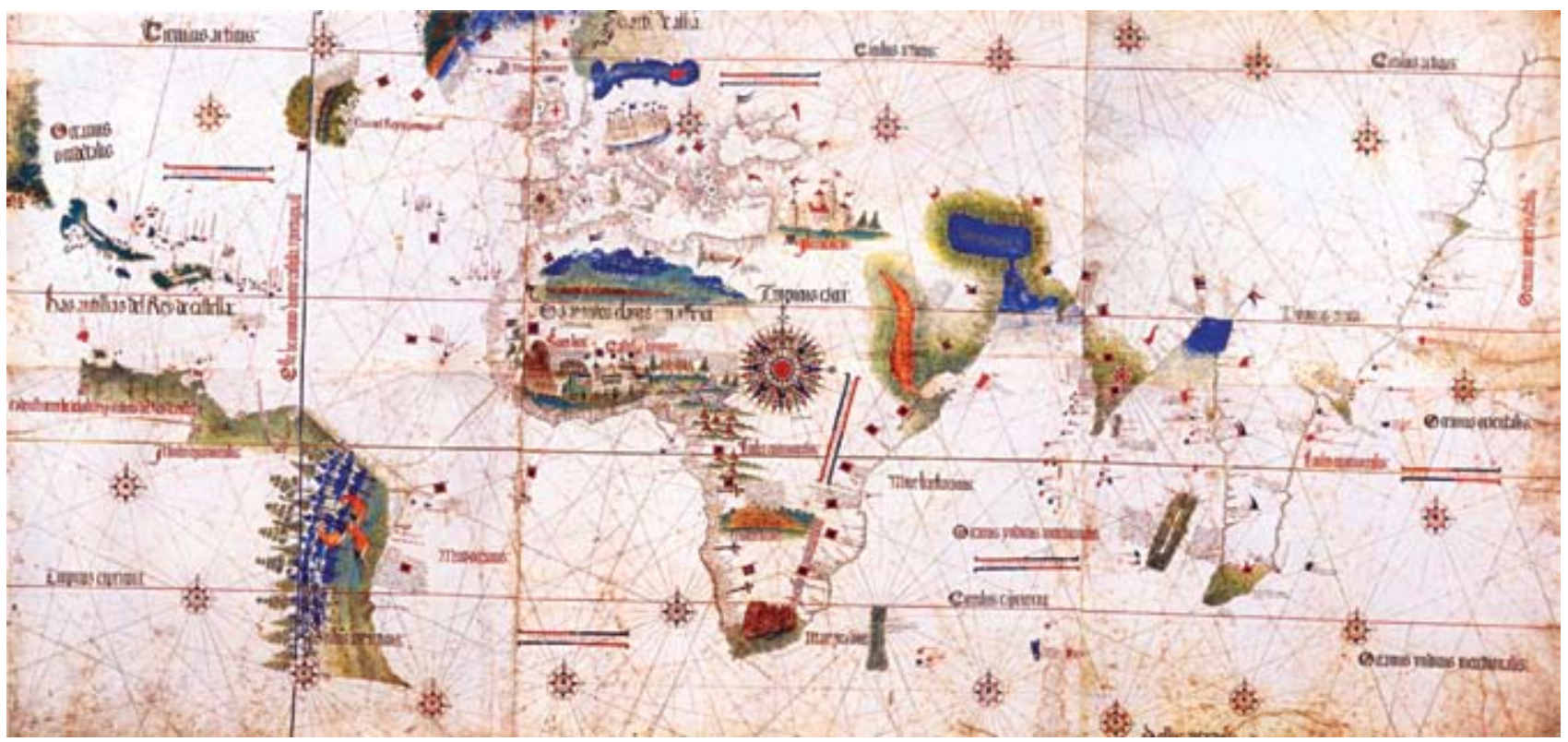

Figura 1 - [Planisfério de Cantino], 1502. Modena, Itália, Biblioteca Estense Universitária. Fonte: Teixeira (2008).

abandono do paradigma ptolomaico - o qual se mantém na representação do Golfo Pérsico e em algumas das legendas. Inclusive pode crer que o cartógrafo o seu trabalho. Acontece que, na representação do continente, colocou-se a grande e principal rosa-dos-ventos. Não figura a escala de latitudes, que já se registrava em outro mapa português da época, mas as linhas equinocial, do trópico de Câncer, a do trópico de Capricórnio e a do círculo Ártico lá se encontram desenhadas. Em projeção cilíndrica quadrada. Pode-se supor que, nas margens (hoje cortadas), liam as latitudes - o meridiano graduado, como se vê no mapa de Caverio, que, em grande parte, é uma cópia do Cantino. E ainda, de importância capital num - de inícios do século XVI, a linha de Tordesilhas - figura da linha que de fato não podia traçar ${ }^{13}$. O mar Roxo (mar Vermelho) - do Bab-el-Mandeb até Suez - só se desenhará com rigor em 1540, pela mão de D. João de Castro, que é o autor do Roteiro do Mar Roxo, resultado de observação e de cálculos astronômicos, o que representou um grande avanço científico em sua época ${ }^{14}$ (Figuras 2).

São diferentes os cuidados que se vêem nas representações do Novo Mundo - no Norte e no Sul. O mapa de Cantino foi desenhado depois da chegada de Cabral a Vera Cruz, em 1500, e pouco depois do retorno da expedição de 1501-1502, de Gonçalo Coelho, na qual figurava Américo Vespuccio (no que seria a sua terceira viagem, chegada a Lisboa em março de 1502). Mas ainda não recebe a contribuição de João da Nova, a itha da Ascensão tenha sido descoberta por um dos navios de Cabral, também no regresso, em 1501. Em 19 de novembro, Alberto Cantino estava já em Roma, de onde
13. Ver Armando Cortesão (1975).

14. Armando Cortesão e A Teixeira da Mota (1960). 


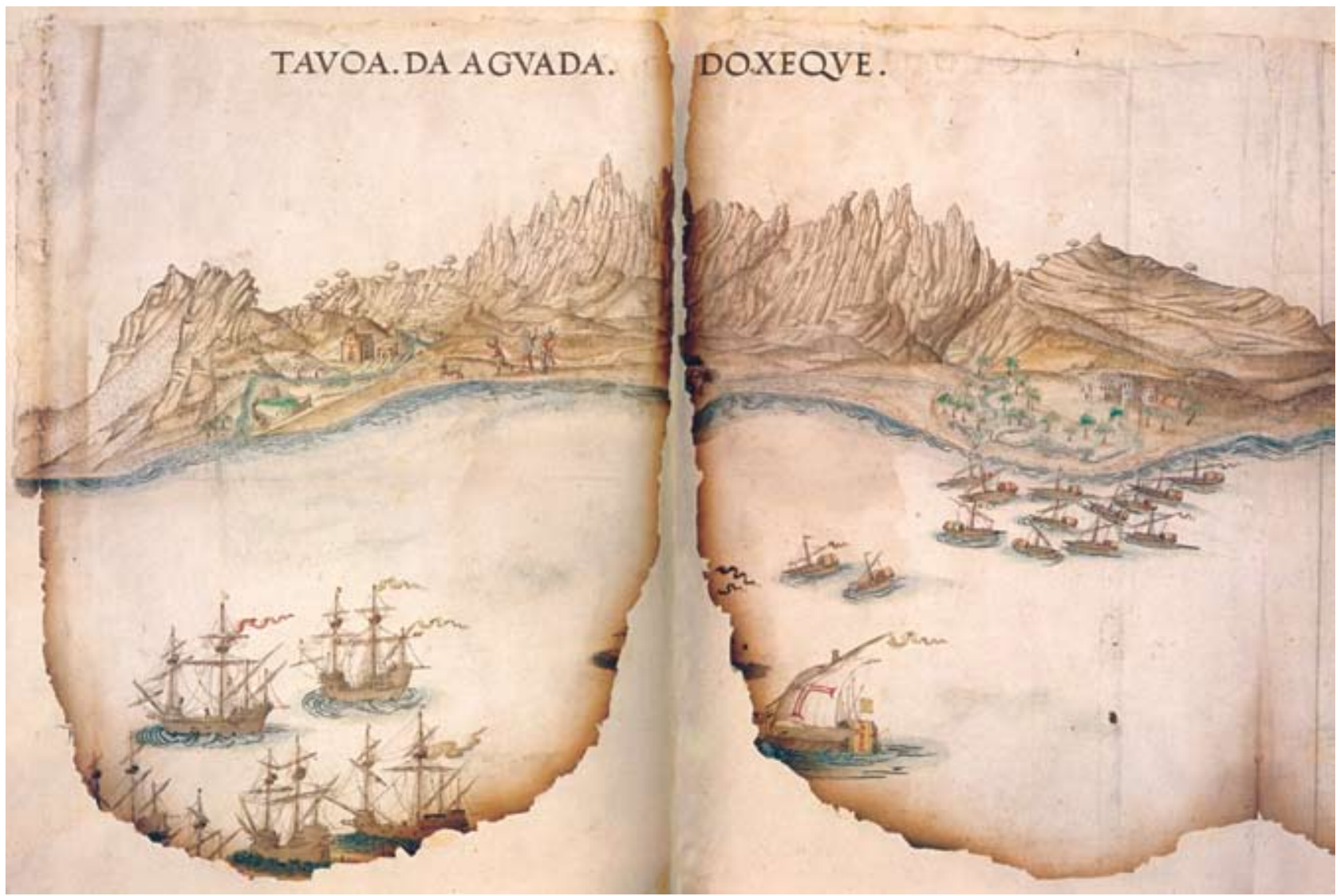

Figura 2 - Roteiro do Mar Roxo de dom João de Castro, 1540. Londres, British Library, Ms. Cott. Tib. DIX. Fonte: Albuquerque e Cotton (1991).

escreve ao duque e anuncia o envio do planisfério - pelo qual pagou 12 ducados de ouro. Pode, pois, dizer que o mapa recebeu uma última mão por setembro-outubro de 1502. Assim, o cartógrafo - e imaginamos que o autor do protótipo do qual temos uma cópia parcial - tinha muitas e novas informações para acrescentar ao padrão real. Porque por sua vez, foi daí copiado clandestinamente o exemplar magnífico que conhecemos. Porque o rei não permitia a divulgação dos mapas nem dos globos terrestres. Este mapa de 1502 é a cópia de um mapa aberto não-completo --, aguardando pelas novidades que podiam vir das novas descobertas. Ao contrário dos - interpretativos, nele não se demonstrou nada. No planisfério vemos já a costa leste do Brasil. Ainda com muito poucos topónimos - mas serão, quase todos, os definitivos - e numa caligrafia diferente da do resto do mapa. Américo Vespuccio, o futuro piloto-mayor da Casa de la Contratación a Indias, não desenhou ou não passou os seus papéis para os Armazéns reais. Porque ali a costa do Brasil se acha muito mal documentada. No interior, vêem-se três araras e 26 árvores de pau-brasil. E, como não admira, nenhum acidente geográfico. Muitas anomalias podem ser detectadas no planisfério, inclusivamente 
as legendas de duas mãos diferentes. A ponto de não ser impossível que seja uma peça roubada antes de concluída - uma boa hipótese. $\bigcirc$ que também confirma que se trata de um mapa de luxo, para oferecer a alguém ${ }^{15}$.

Ao datar o Cantino de fins de 1502, há que acrescentar que os portugueses ainda não conhecidam muito bem a Ásia, a ponto de registrarem com muito rigor os topônimos asiáticos. Grande parte das informações das legendas foi obtida junto mercadores orientais. Porque mercadorias o que as armadas portuguesas procuravam - como se lê em muitas das legendas do mapa. Em 1502, os portugueses não tinham ainda a possibilidade física de ter recolhido diretamente novas informações.

A cartografia portuguesa de Quinhentos ganha muito maior rigor geográfico pela generalização da observação astronômica. Os pilotos medem a altura da estrela polar e muito mais a do sol - no hemisfério Sul, mas não só. E logo na cartografia se fixa e apresenta a tábua de latitudes. Há que perguntar se isso implicou a introdução da ideia e o traçado de uma projeção. E qual projeção? Mas não parece provável. $\bigcirc$ que se passou foi a continuidade com o registro do rumo magnético e a estima das distâncias percorridas da maneira tradicional, acrescidas e com as latitudes, sendo que as longitudes continuaram a ser estimadas pelas distâncias percorridas. $\bigcirc$ que ao alargar-se a todo o globo multiplica os erros $^{16}$. Mas a grande dificuldade de traçar as linhas junto ao Norte e ao Sul do planeta leva a que se imponham as escalas oblíquas - junto da Terra Nova, para dar um exemplo. A maior dessas dificuldades é sempre a que resulta da impossibilidade de medir a longitude. Havia que arbitrar umas tantas léguas por grau percorrido. $\bigcirc$ que provoca não poucas confusões. $\bigcirc$ que por então não vai ter uma solução definitiva. Mas os esforços dos portugueses vão no caminho do aperfeiçoamento da representação do planeta ${ }^{17}$.

Uma e outra vez temos de voltar ao planisfério de Cantino.Porque, além da quase perfeita representação da África, tem já bons troços da Ásia e do Novo Mundo. Ao começar a cartografar a Ásia, sabia-se que, além do mais, herdavam-se informações dos próprios asiáticos e dos árabes, sempre com a atenção devida a Ptolomeo. Ora, em 1502, os portugueses "expulsaram Ptolomeo" da representação da Ásia. Foi o que fez o cartógrafo anônimo do Cantino, porque os portugueses tinham já recomposto o mapa oriental com dados asiáticos. Ao chegar ao Índico e ao Pacífico as novidades serão ainda mais intensas. E uma vez mais, também, o reencontro com Castela e a necessidade de dirimir a dificuldade posta pelo tratado de Tordesilhas, agora pelo que respeita ao antimeridiano, cuja necessidade de traçado se descobria. As estimas no Índico e no Pacífico vão sendo melhoradas, e a conclusão será a que as Malucas ficam no hemisfério português e não no castelhano. Melhoram-se muito os mapas com a inclusão dos desenhos feitos à vista dos locais. Desenhos "tirados do natural", como se dizia"18.

Mas outros países da Europa também querem participar nos tratos ultramarinos. E para isso vão atrair pilotos e cartógrafos portugueses. $\bigcirc$ que leva a que se desenvolva, na França, uma escola de cartografia de produção franco-portuguesa. Os mapas portugueses da segunda metade do século XVI vêm
15. Ver os textos de Maria Fernanda Alegria (1995); e, da mesma autora, com João Carlos Garcia (1991); e ainda, deles dois com Francesc Relaño (1998)

16. Ver Duarte Leite (19591960); e A. Fontoura da Costa (1939).

17. Ver A. Teixeira da Mota (1973).

18. Ver Armando Cortesão (1978). 
19. Cf. textos do Atlas Miller (2003).

20. Cf., sobre o mapa, o artigo Roteiro de Todos os sinais (1965). muitas vezes em Atlas. Que, seguramente, destinavam-se ao estudo e à satisfação da curiosidade geográfica. Mas influíram na cartografia que começa agora a crescer, que é a holandesa. Com o fundamental Theatrum Orbis Terrarum, de Abraham Ortelius, de 1570. E, em seguida, acontece a revolução introduzida por Mercator, em 1590, com o seu Atlas sive cosmographicale meditaciones de fabrica mundi et fabricati figura. Há ainda a considerar que a muito boa e moderna cartografia passa também a ser impressa a partir dos trabalhos dos gravadores mais hábeis e reproduzida nas melhores tipografias, que são as de Flandres. E vêm a seguir os famosos Neptune, que amplificam a cartografia em quantidade e em qualidade.

Muitos serão os mapas do Brasil, e muitos deles em Atlas manuscritos de luxo. Há que referir a preciosa folha do Atlas Miller, de Lopo Homem-Reinéis, de enorme beleza ${ }^{19}$. Mas a grande novidade sobre o Brasil vai surgir com o Roteiro de todos os sinais, de 1586, de Luís Teixeira, que, com detalhes, nos mostra os mais importantes troços das costas, já com as povoações que estavam a crescer dos inícios da colonização. Como acontecia nos velhos portulanos, o interior mostra-se muito desguarnecido. Quando muito, no mapa geral do território de Sul para Norte a representação de um rio - que será o Amazonas - e de Norte para Sul um outro - que representa o rio da Prata. Quase unidos, ou mesmo saindo de um mesmo lago, cada qual para sua banda. Corresponderá isso à concepção do Brasil como uma ilha, precoce intento mítico, de concepção local, para marcar a separação das conquistas de Portugal e de Castela? Que, a cartografia vai difundir? E ainda empurrada para leste, a fim de incluir o rio da Prata no hemisfério português: o que foi dito como uma "gigantesca falsificação cartográfica" - que vai perdurar. A presença portuguesa no Brasil só vai acontecer depois de provados os grandes lucros do açúcar. É só no século XVII que a penetração para o interior de São Paulo, com as expedições para caçar escravos índios, vai proporcionar o conhecimento de acidentes geográficos, em especial pelos rios. Porque, como os rios na América do Sul em geral correm muitas léguas de leste para oeste, eles eram a via de penetração no interior do continente. E essa vai ser a rede de comunicação dos portugueses. A cartografia portuguesa do Brasil tem a vantagem de criar uma coisa nova, sem concorrência. E essa novidade vai ser possível por dois séculos mais - até à independência em 1822.

O Roteiro de todos os sinais, conhecimentos, fundos, baixos, alturas e derrotas que há na costa do Brasil desd'o Cabo de Santo Agostinho até o Estreito de Fernão de Magallães tem 12 desenhos, que correspondem a descrições de rotas úteis (Figuras 3 e 4). Um pequeno exemplo: "Primeiramente devo saber que el Cabo de Santo Agostinho está em altura de oito grados e meo he terra baixa e tem muito arvoredo junto do mar, e parecem alguns campos sem arvores". Mas há mais indicações. O mapa final, onde está representado todo o território - do Amazonas à Terra do Fogo -, tem na vertical uma tábua de latitudes - de 2 Norte a 53 Sul. Na horizontal, tem uma escala de 100 léguas repartidas por 2, 10 e $50^{20}$.

Nos Atlas portugueses do período dito de esplendor (séculos XVI-XVIII, vamos encontrar muitos onde se representa o Brasil. A grande colônia portuguesa 


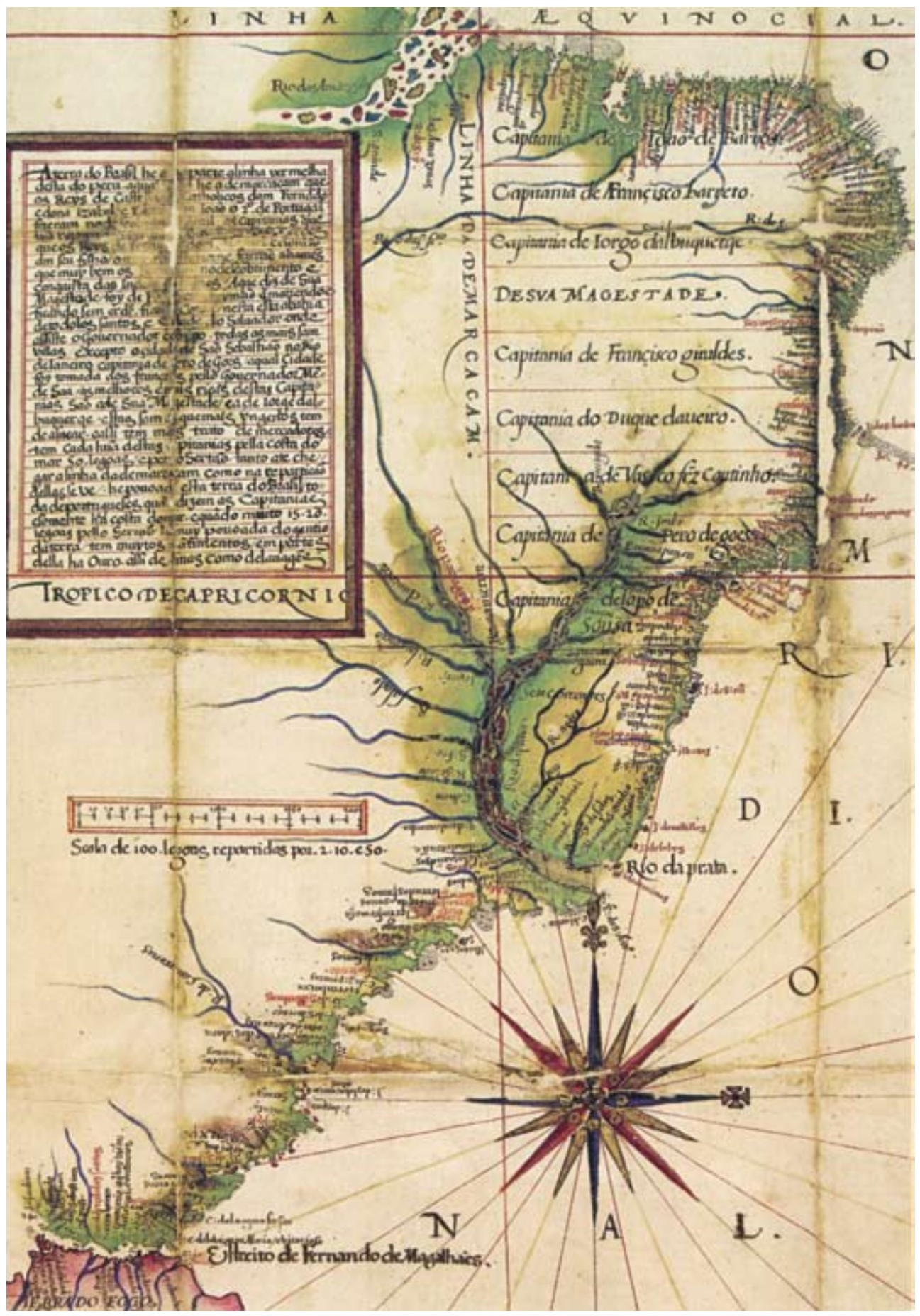

Figura 3 - [As capitanias do Brasil e o litoral da América do Sul entre a foz do Amazonas e a Terra do Fogo], Luis Teixeira in Roteiro de todos os sinaes, conhecimentos, fundos, baixos, alturas e derrotas, que ha na Costa do Brasil, desde cabo de Santo Agostinho até o estreito de Fernão de Magalhães, (Ca. 1585-1590), folio 34. Biblioteca Nacional de Portugal, Lisboa, 2008. 


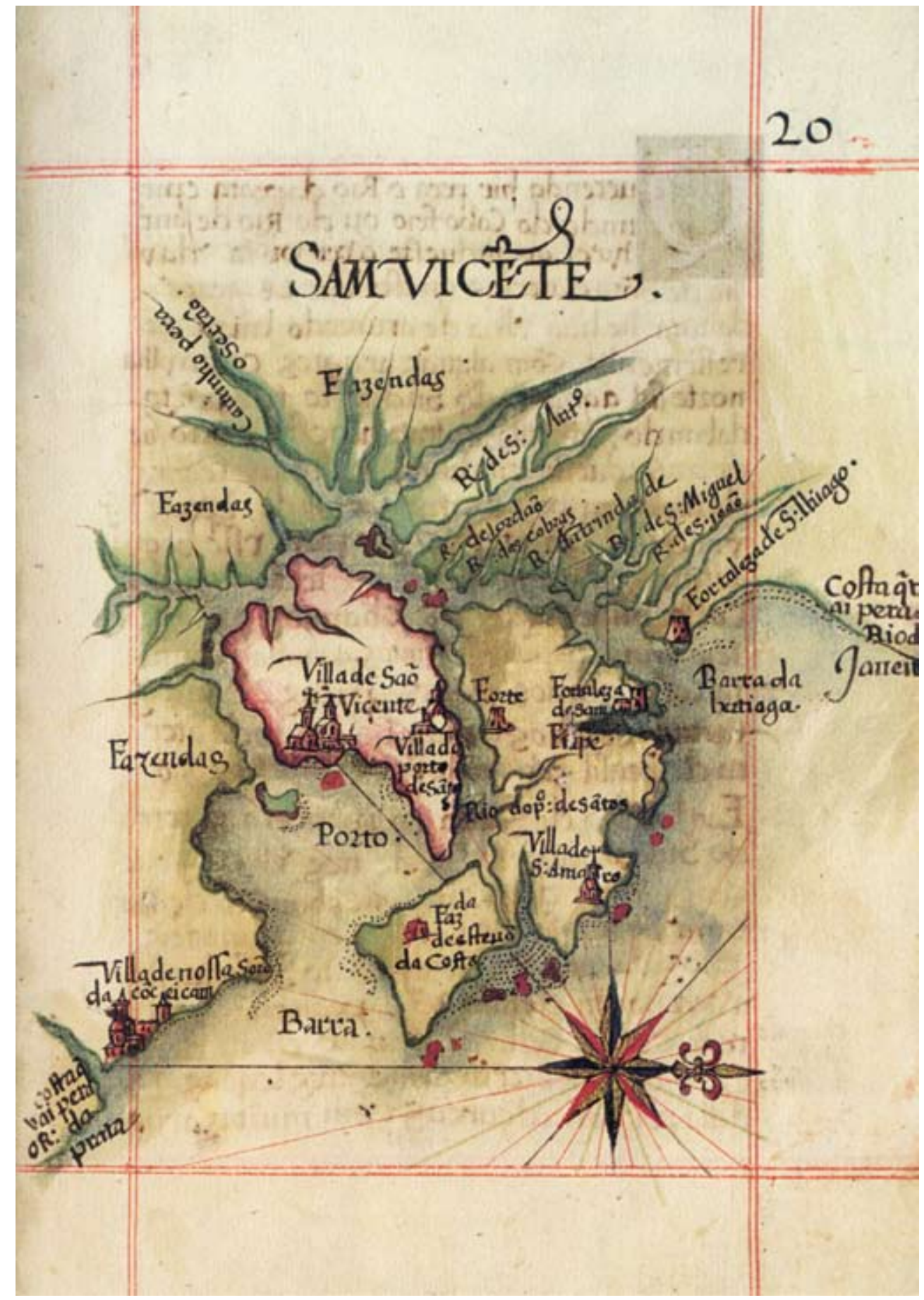

Figura 4 - [Mapa da barra de Sam Vicente], Luis Teixeira in Roteiro de todos os sinais, conhecimentos, fundos, baixos, alturas e derrotas, que ha na Costa do Brasil, desde cabo de Santo Agostinho até o estreito de Fernão de Magalhães, (Ca. 1585-1590), fólio 20. Biblioteca Nacional de Portugal, Lisboa. 
vai destacar-se no conjunto do império. Porque era um espaço imenso - de dimensões continentais -, porque era o mais rico do domínio português, pela produção do açúcar. $\bigcirc$ que impunha que fosse conhecido e representado. Além disso, a busca de índios para o interior, e a concomitante pesquisa do ouro, ia impor que se percorressem os rios e se reconhecesse o território. Há vestígios de desenhos muito frustres de itinerários, o que ainda não é cartografia. Uma das expedições ao interior - de Belém do Pará a Quito, por Pedro Teixeira, em 1637-1638 - provocará outras expedições que proporcionaram elementos de conhecimento empírico do território ${ }^{21}$. E provocarão registos cartográficos. Frutos da observação e de informações que se iam recolhendo. Inclusive pode pensar-se que os índios faziam representações em que miniaturizavam o seu mundo. Que era maior do que se supõe, porque eles eram grandes andarilhos. E conheciam muito bem as florestas e os rios tropicais.

Nas cartas-portulanos o que interessava ao cartógrafo eram as representações das costas. Certas deformações explicam-se mesmo por essa razão. Um cabo mais difícil de passar, uma praia inconveniente para desembarque terão mais destaque. Porque nas cartas há sempre elementos de reconhecimento indispensáveis à navegação, elementos que são essenciais nos roteiros. $E$, por mais que se aperfeiçoem os mapas, são roteiros e descrições de rotas marítimas que continuam a ser indispensáveis para a navegação ${ }^{22}$. E por isso também muito controlados para evitar que fossem parar ao estrangeiro. Inventaram-se duas maneiras para conjugarem-se as necessidades de ambos os instrumentos: misturar os dois tipos de informação num manuscrito ou numa publicação - e isso é o caso do Roteiro do Mar Roxo, de D. João de Castro, e do que podemos chamar Roteiro do Brasil, de 1586, ou de outros - de que resulta a descrição literária, o desenho em plano da costa e, ao mesmo tempo, a sua vista em elevação. Isto significa impor à cartografia uma distorção que permita, em simultâneo, apresentar o mapa e os elementos constitutivos dos roteiros: foi a solução adotada com imenso êxito nos Países Baixos por Lucas Janszsoon Waghenaer, misturando a projecção vertical com a projecção oblíqua, como se o observador estivesse no mar, em seus Spieghel der Zeevaerdte Thresoor der Zeevaert (Espelho dos navegantes; e Tesouro dos navegantes) ${ }^{23}$. E, para responder às práticas da navegação costeira, algo de semelhante foi adotado nos roteiros portugueses do Brasil.

No século XVII, de 1630 a 1654, dá-se a ocupação neerlandesa do Nordeste brasileiro. E, com ela, a chegada de um cartógrafo, o alemão Georg Marcgraff, geógrafo, astrônomo e naturalista, que tinha estudado em Leiden e que teve como tarefa desenhar os mapas dos novos domínios holandeses. O que vai representar um avanço notável. Rerum per Octennium in Brasilia, de Gaspar Barleus, é uma espécie de relação de tudo o que se passou no governo de Johan Maurits von Nassau-Siegen. Aí figura a magnífica cartografia de Marcgraff, também ilustrada com preciosos pormenores do pintor Frans Post. Também utilizando fontes portuguesas Apesar de estar excomungada pela sua origem protestante, o rei de Portugal D. João IV obteve um exemplar da obra. Nesse período, os holandeses fizeram muitos mapas, alguns de muito interesse para
21. Ver Max Justo Guedes (1987).

22. Ver Suzanne Daveau (1991); e Inácio Guerreiro (1997b).

23. Ver H. Gabriel Mendes (1969). 
24. Ver Max Justo Guedes (1999).

25. John M. MONTEIRO, Negros da Terra, op. cit.,. Ver a edição fac-similar de Descripção de todo o maritimo da Terra S. Cruz (2000).

26. Ver Numa Broc (1975)

27. Ver Jaime Cortesão (1964). marcar a presença holandesa no Brasil, mas também na África. Devem recordar-se os mapas que incluem os territórios africanos, desenhados, nos primeiros anos da conquista, por Cornelis Bastiaansz(soon) Golijath. Não pode esquecer que os holandeses necessitavam da conquista da África para garantir o fornecimento de escravos às suas novas colônias de Pernambuco ${ }^{24}$. Ao mesmo tempo, continuam a desenhar-se Atlas e mapas portugueses do território, que bem confirmam como era deficiente o conhecimento do interior. Mesmo do interior imediato. $\mathrm{Na}$ Descripção do Brasil, de 1642, de João Teixeira Albernaz vê-se a grande lagoa chamada Lagoa dos Patos. Mas a menor, a Lagoa Mirim, nem sequer está dito que exista. Porque, como também se vê nos desenhos, do Rio da Prata até São Vicente, não havia ainda nenhuma povoação (Figuras 5, 6, 7 e 8). Só em redor de São Vicente-Santos começam as representações de povoados. E com muitos vazios ainda. O Brasil só estaria já bem ocupado em torno do Rio de Janeiro, de Salvador da Bahia, e em redor de Olinda, na capitania de Pernambuco ${ }^{25}$. Eram as regiões açucareiras. Mas a cartografia portuguesa do período já não é um trabalho de primeira importância para o Estado. Pode dizer-se que então se caíu num período de inércia. Os verdadeiros interesses portugueses dos anos da restauração da independência política (1640-1668) empurram a cartografia portuguesa para o conhecimento das raias com Castela, na Península Ibérica, suas fortalezas e obras de defesa. Tanto pior, porque agora as exigências científicas se impõem, depois da criação, em 1666, da Académie Royale des Sciences de Paris e do Observatoire. Impõe-se tratar da elaboração científica dos mapas. As longitudes passam a medir-se pelos eclipses dos satélites de Júpiter; dinamiza-se a construção e a utilização do cronômetro. Vai passar o tempo das estimativas e da velha cartografia. Agora a astronomia e a trigonometria comandam. A Académie des Sciences não tarda a enviar expedições científicas para vários pontos do mundo. Em 1682 se desenhou o grande planisfério de Jean-Dominique Cassini, um marco da modernidade científica ${ }^{26}$.

No Brasil continuam a fazer-se mapas de utilidade imediata, para as necessidades da navegação e do comércio. Mas são cartas sem rigor - se bem que suficientes para a orientação nas costas de um mar bem conhecido ${ }^{27}$. $O$ grande desenvolvimento na apreensão da terra brasileira vai necessidades trazidas pelo conflito em redor do Rio da Prata e da demarcação dos territórios portugueses e espanhóis na América do Sul. E, assim, entramos nos grandes problemas do século XVIII.

Sabe-se que o rei de Portugal queria a divisão da América do Sul pelo Amazonas e pelo Rio da Prata. Para o conseguir, mandou construir, uma fortaleza - a Colônia do Sacramento - na margem esquerda do estuário platino. Iso passou-se em 1680. Mas por ali nunca houve paz, senão provisoriamente, mesmo tendo sido muito o contrabando da prata. Por meados da primeira metade do século, D. João $V$ compreendeu o atraso português nas ciências matemáticas e fundou o Observatório de Lisboa, empurrando o engenheiro-mor Manuel de Azevedo Fortes para que publicasse uma obra ensinando as regras da cartografia (1722 e 1729). Fez vir numerosos instrumentos astronômicos do estrangeiro. Além 


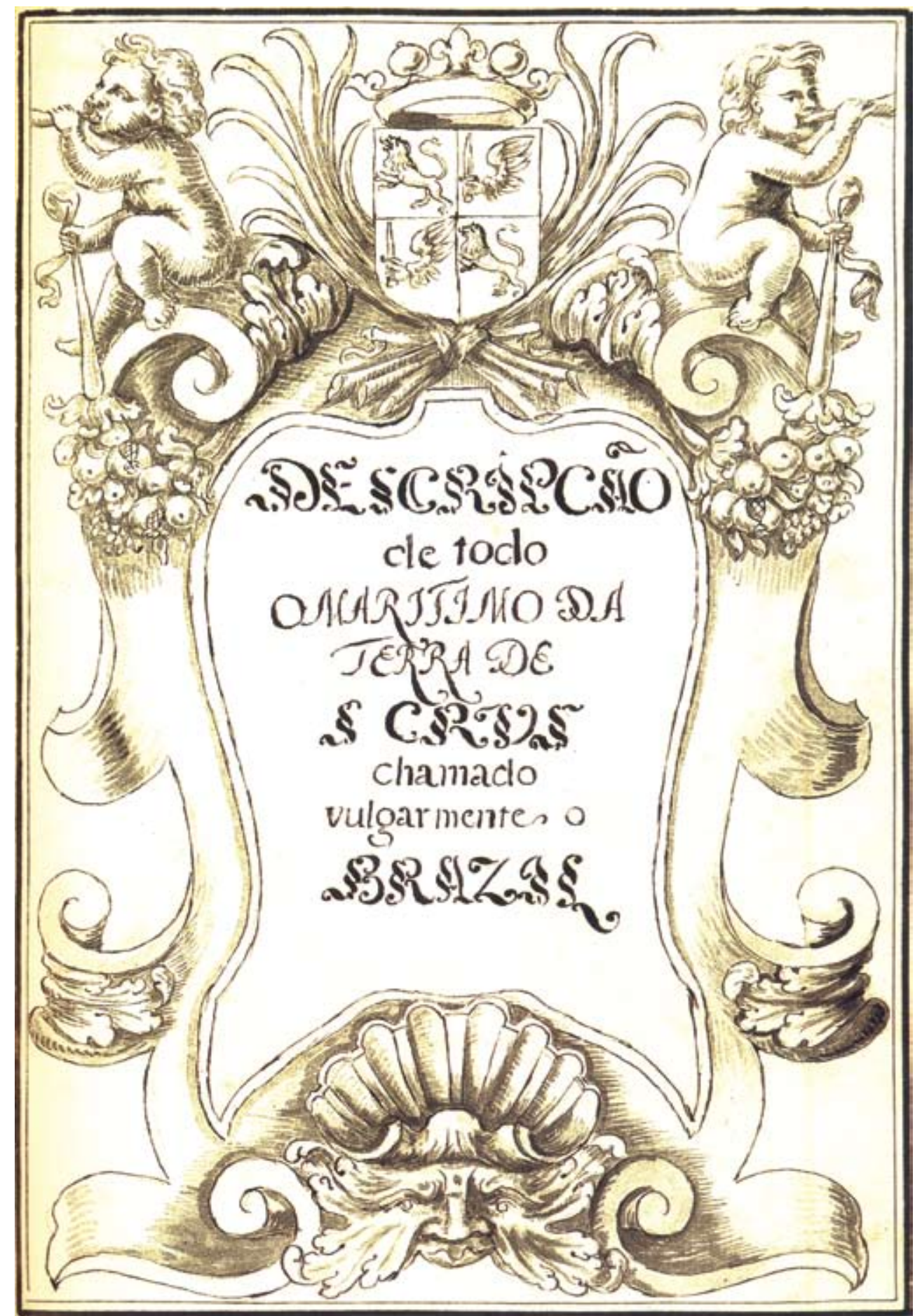

Figura 5 - João Teixeira Albernaz, Descripção de todo o marítimo da terra de Santa Cruz, vulgarmente chamada de Brasil, c. 1654, manuscrito aquarelado 131 cartas parciais do litoral brasileiro). Coleção Brasiliana/Fundação Estudar Pinacoteca do Estado, São Paulo. Fonte: Descripção..., 2004 


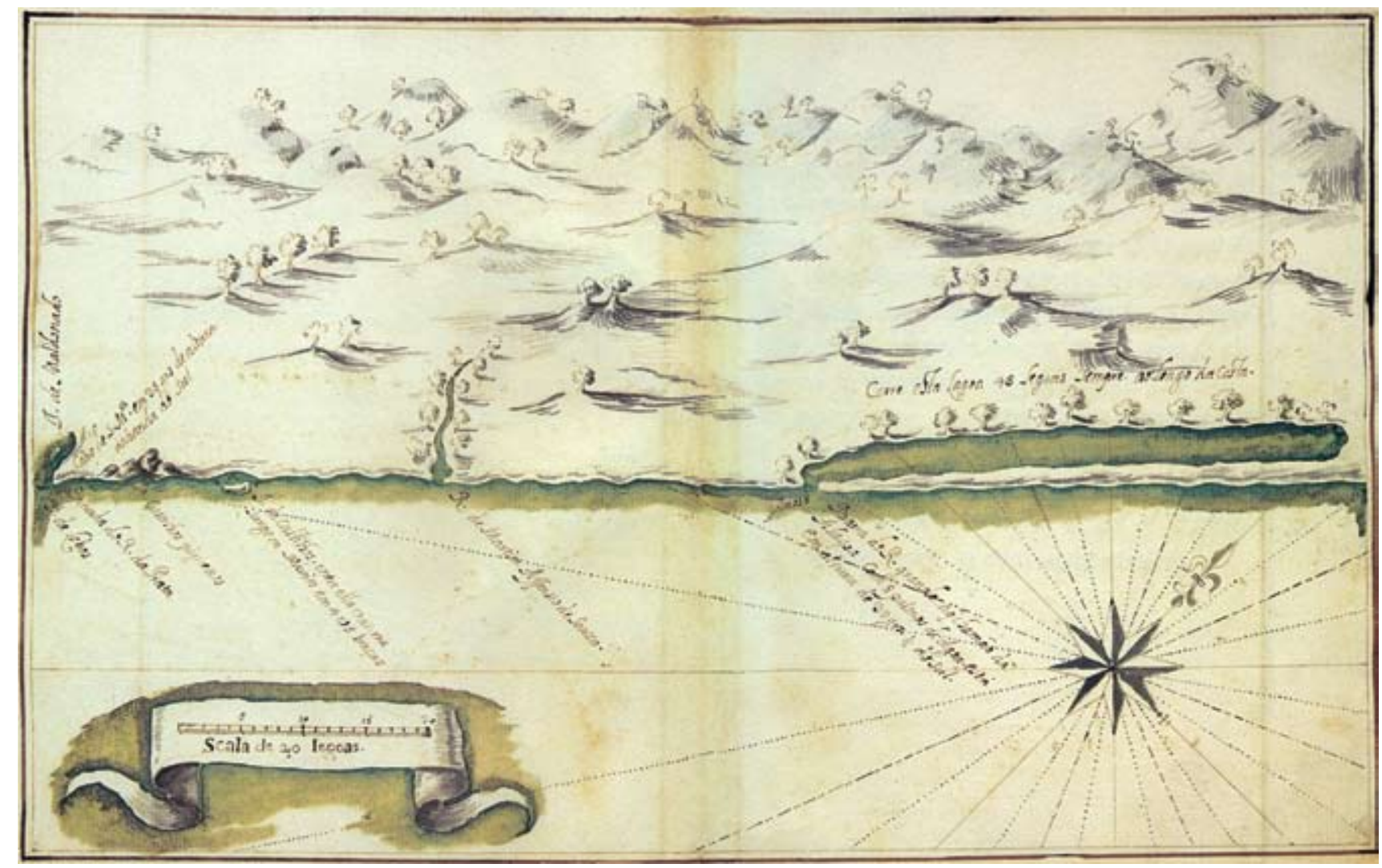

Figura 6 - [Do cabo de S. Maria que he a ponta da banda do Norte do Rio da Pratta..., Carta 2], João Teixeira Albernaz, Descripção de todo o marítimo da terra de Santa Cruz, vulgarmente chamada de Brasil, c. 1654, manuscrito aquarelado 131 cartas parciais do litoral brasileiro). Coleção Brasiliana / Fundação Estudar, Pinacoteca do Estado, São Paulo. Fonte: Descripção..., 2003.

28. Ver Beatriz P. Bueno Siqueira (2002).

29. Sobre o assunto, ver Max Justo Guedes (1997b); e André Ferrand de Almeida (2001a; 2001b). disso, apoiou e determinou um levantamento cartográfico rigoroso do Brasi|28. Por não haver especialistas em Portugal, para o fazerem, chamou, da ltália, Domenico Capassi e Giovanni Battista Carbone, dois padres jesuítas peritos em geografia - bons matemáticos, como se dizia. Na Península fizeram a sua preparação e só um deles, Capassi, passou ao Brasil, em companhia de um outro padre, o português Diogo Soares. lam para desenhar a cartografia da colônia. O rei queria a constituição de um Novo Atlas do Brasil. O que não se cumpriu. Passaram primeiro pela Colônia do Sacramento, e, depois, pelo Rio de Janeiro. Do padre Capassi pouco ficou feito, pois morreu quase em seguida. Mas o padre Soares fez um trabalho muito rigoroso e muito extenso ${ }^{29}$. Em seus mapas, tomou como coordenada o meridiano do Rio de Janeiro, fugindo assim dos problemas postos pela linha de Tordesilhas. Mas não pode dizer que seu objetivo - ao contrário do que se pensou - fosse em especial a demarcação da fronteira com a Espanha. Pelas peças desenhadas assim se vê. Mais parece que a preocupação era com a demarcação das raias internas entre as unidades administrativas de governo e das dioceses. Porque, com a descoberta do ouro em Minas Gerais, o Brasil enriquecia-se e se 


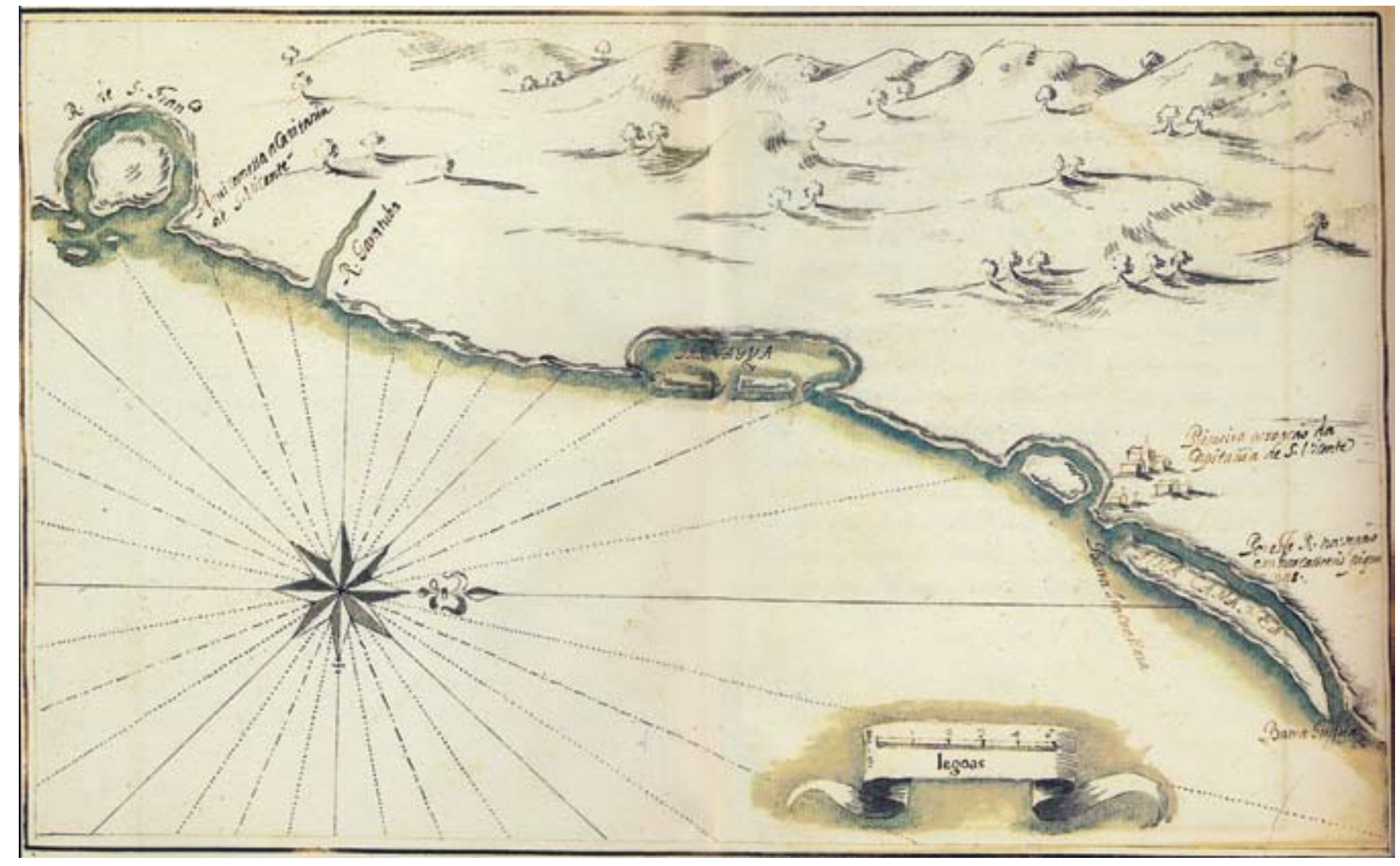

Figura 7 - [Do Rio S. Francisco até a costa a que chamão da Cananea..., Carta 4], João Teixeira Albernaz, Descripção de todo o marítimo da terra de Santa Cruz, vulgarmente chamada de Brasil, c. 1654, manuscrito aquarelado 131 cartas parciais do litoral brasileiro). Coleção Brasiliana/Fundação Estudar, Pinacoteca do Estado, São Paulo. Fonte: Descripção..., 2003.

povoava muito rapidamente. Havia que organizar uma administração que cada dia se tornava mais complexa. Governos, municípios, dioceses, paróquias, arranjar os espaços de tudo isso e evitar os conflitos regionais e locais, explosivos numa sociedade tão conflitiva e cheia de contrastes como era aquela ${ }^{30}$. (Figura 9)

Entretanto, no Norte, no estado do Maranhão, o conhecimento da terra e a sua cartografia começa a levantar grandes dificuldades. E isso por causa da demonstração, em Paris, perante a Académie Royale, pelo geógrafo Guillaume Delisle a respeito do novo mapa que propõe. D. Luís da Cunha, o embaixador português na França, intrometeu-se a negociar a não publicação de uma prova científica que não era satisfatória para o rei de Portugal (Figura 10). Mas sem resultado. Da melhor maneira que pôde, procurou atrair Jean-Baptiste Bouguignon d'Anville, um outro geógrafo francês, assinalando-the um bom trabalho em África. O que deu resultado, provindo daí um excelente mapa do interior do Sul do continente africano. E também a construção de cartas da América do Sul, o que fez entre 1742 e 1748.

Mas as fronteiras do norte do Brasil continuavam sendo controversas.
30. Ver Jaime Cortesão (1983-1984) 


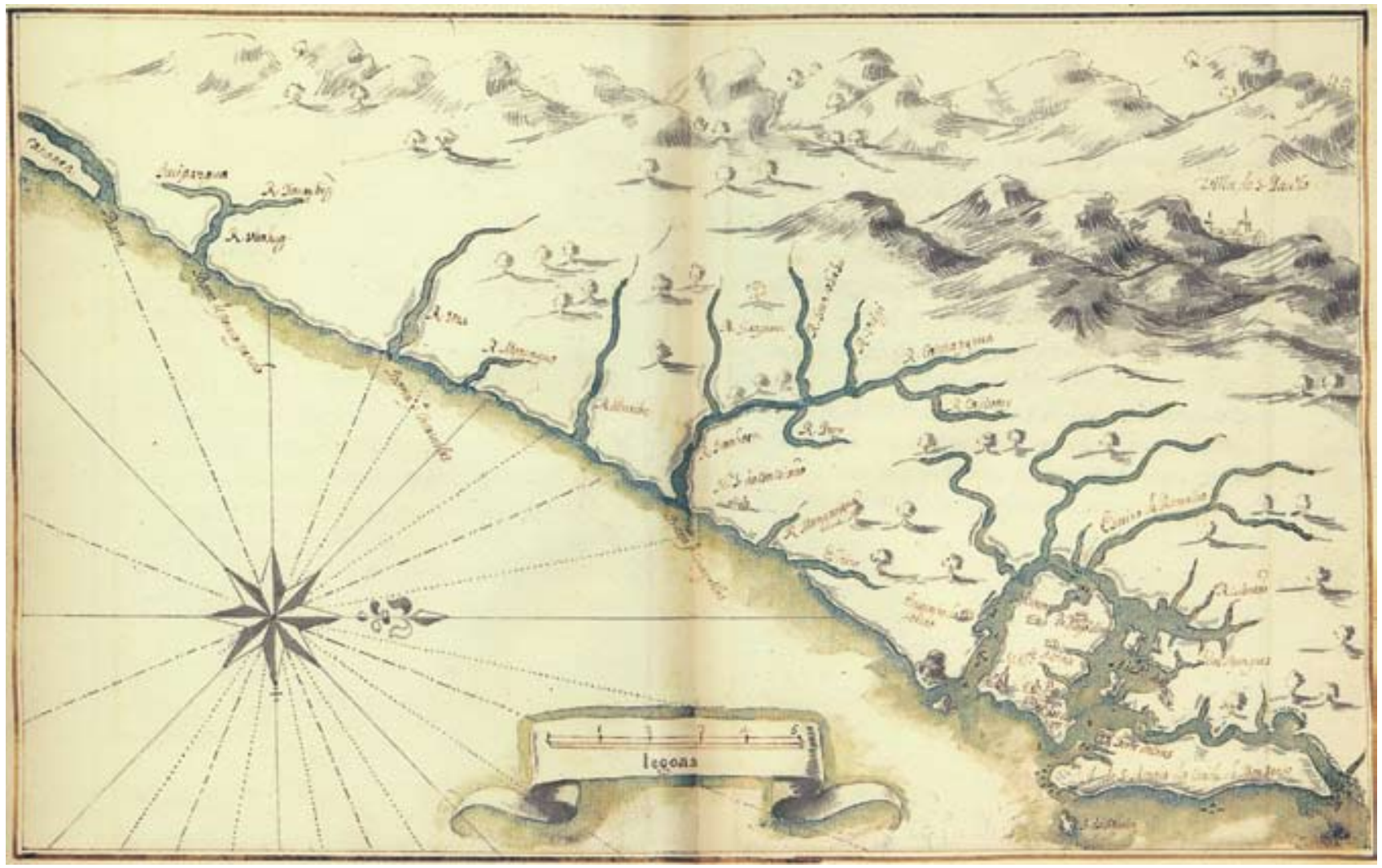

Figura 8 - [Mostrase a costa que vem do Rio e llha da Cananea ate o porto de S. Vicente..., Carta 5], João Teixeira Albernaz, Descripção de todo o marítimo da terra de Santa Cruz, vulgarmente chamada de Brasil, c. 1654, manuscrito aquarelado 131 cartas parciais do litoral brasileiro). Coleção Brasiliana/Fundação Estudar, Pinacoteca do Estado, São Paulo. Fonte: Descripção..., 2003.

31. Ver Carlos Maria de La Condamine (1944).
Em especial negavam-nas os jesuítas, os que melhor conheciam a região, o que dificultava a posição portuguesa. Também da maior importância é o mapa de Charles Marie de La Condamine, desenhado durante a viagem de uma missão científica francesa pelo Amazonas e publicado pela primeira vez en 1745 (Figura 11). Esse corrigia o anterior, de 1691, do Padre Samuel Fritz, impresso várias vezes (Figura 12) Já La Condamine, pela observação de um satélite de Júpiter, fez uma observação de longitude. Portugal perde o argumento que justificava a plenitude do domínio do vale do Amazonas por incluído na partilha de Tordesillas. Assim se viam os erros da cartografia portuguesa. Vícios antigos, que empurravam - Continente para leste, fazendo-o entrar muito mais do que na realidade devia no espaço português delimitado em Tordesilhas. Mas também se pode pensar que não era apenas o traçado, mas por força da política que assim distorcia a representação da realidade. A forte corrente marítima equatorial levaria também a que a longitude estimada parecesse menor ${ }^{31}$.

Por fim, Portugal e Espanha iniciam as conversações que vão conduzir ao Tratado de Madrid, de 1750. Em Lisboa, o diplomata e secretário do rei 


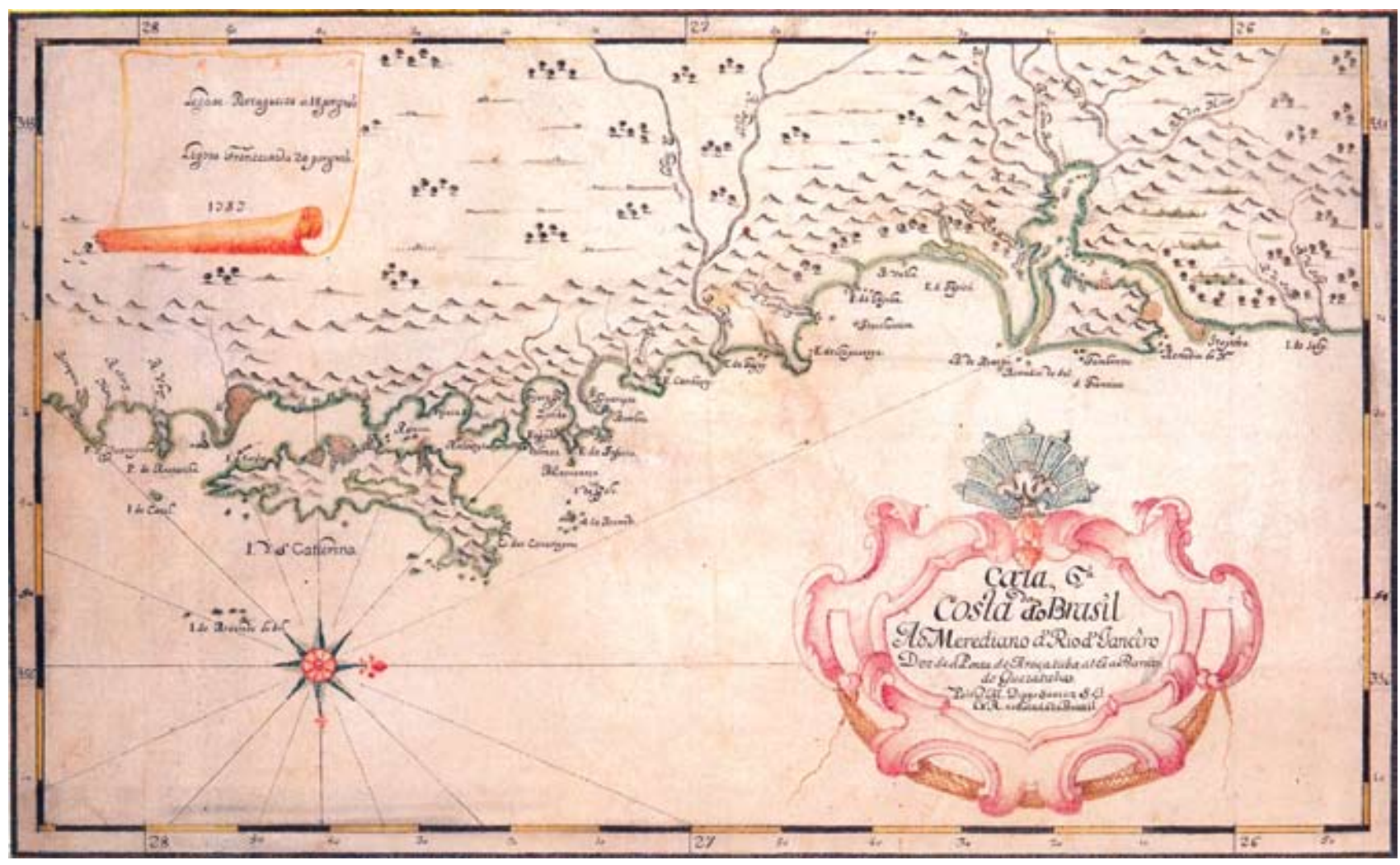

Figura 9 - Carta 6ำ da costa do Brazil ao meridiano do Rio de Janeiro desde a ponta de Araçatuba até à barra de Guaratuba. Diogo Soares (ca. 1737), cópia de 1933-1934, executada a partir do original depositado no Arquivo Ultramarino. Biblioteca do Museu Paulista, São Paulo.

Alexandre de Gusmão (que manobrava as negociações) pedia às autoridades do Brasil toda a informação disponível para sustentar as suas propostas perante o negociador espanhol D. José de Carvajal. E então alguns militares (e alguns mesmo com formação de engenheiros) elaboraram e enviaram novos mapas. Faziam-nos ao mesmo tempo em que se ocupavam das fortificações. Conta com os conhecimentos cartográficos que tinham progredido no Brasil, são feitos alguns mapas de muito interesse - como o chamado mapa Mindlin, de 1746 -, que mostram o progresso que houve no conhecimento do território e as propostas de delimitação que vão. Até chegar ao famosíssimo Mapa das Cortes, que serviu de justificação para a decisão final, que, além de anônimo, não é muito rigoroso (Figura 13). Nele, os portugueses viciavam alguns dados geográficos para sustentar a sua proposta diplomática. Porque se queria mesmo substituir o velho Tratado de Tordesilhas pelo princípio do uti possidetis e demarcar as fronteiras pelos limites naturais. Mas dos dois lados havia quem pensasse que o seu país ia perder. Muitos não queriam o Tratado de Madrid, em Lisboa e em Madrid: o acordo a que se chegou deve-se ao empenhamento de D. João $V$ e da filha $D$. Bárbara de Bragança, casada com

Annals of Museu Paulista. v. 17. n.1. Jan. - June 2009. 


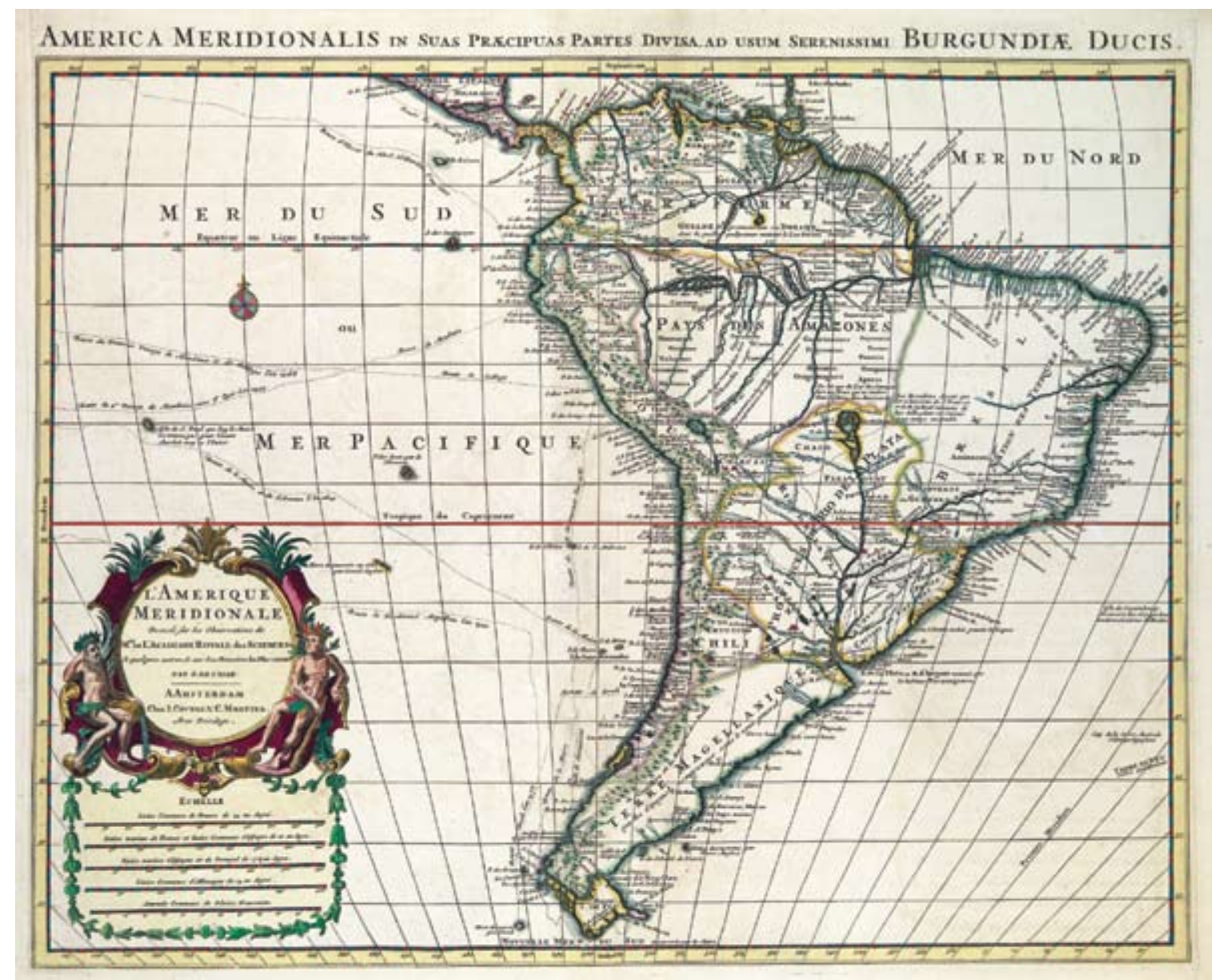

Figura 10 - América Meridionalis, 1722, Guillaume de Delisle, Amsterdam, Covens e Mortier, 1774. Instituto de Estudos Brasileiros / USP (acervo depositado temporariamente pela Justiça Federal), São Paulo.

32. Ver Mário Clemente FERREIRA (2000; 2001; 2007).
Fernando VI e rainha de Espanha. Sabe-se que depois foi necessário enviar geógrafos delimitadores para a América, o que não se completou por causa da suspensão do convênio. Mas o trabalho realizado pelos demarcadores de ambas as partes no Sul do Brasil é de uma qualidade assinalável32.

Em seguida, ainda há notáveis realizações cartográficas no interior. A necessidade de domínio do territorio pelo governo do marquês de Pombal e de D. Maria I, e, depois, do príncipe regente D. João - mais tarde D. João VI -, já em plena vigência das luzes da razão, implicou expedições em que a cartografia tinha um lugar muito especial. Governadores ilustrados iam para a colônia e aí procuravam representá-la bem. Muito em especial, foi o que se passou no Mato Grosso, no interior oeste. Pela descoberta do ouro, havia que bem demarcar o domínio português, sempre ameaçado pelos espanhóis - em particular pelo que respeita à navegação pelos rios Guaporé-Mamoré-Madeira. Era preciso controlar esse espaço para garantir o domínio 


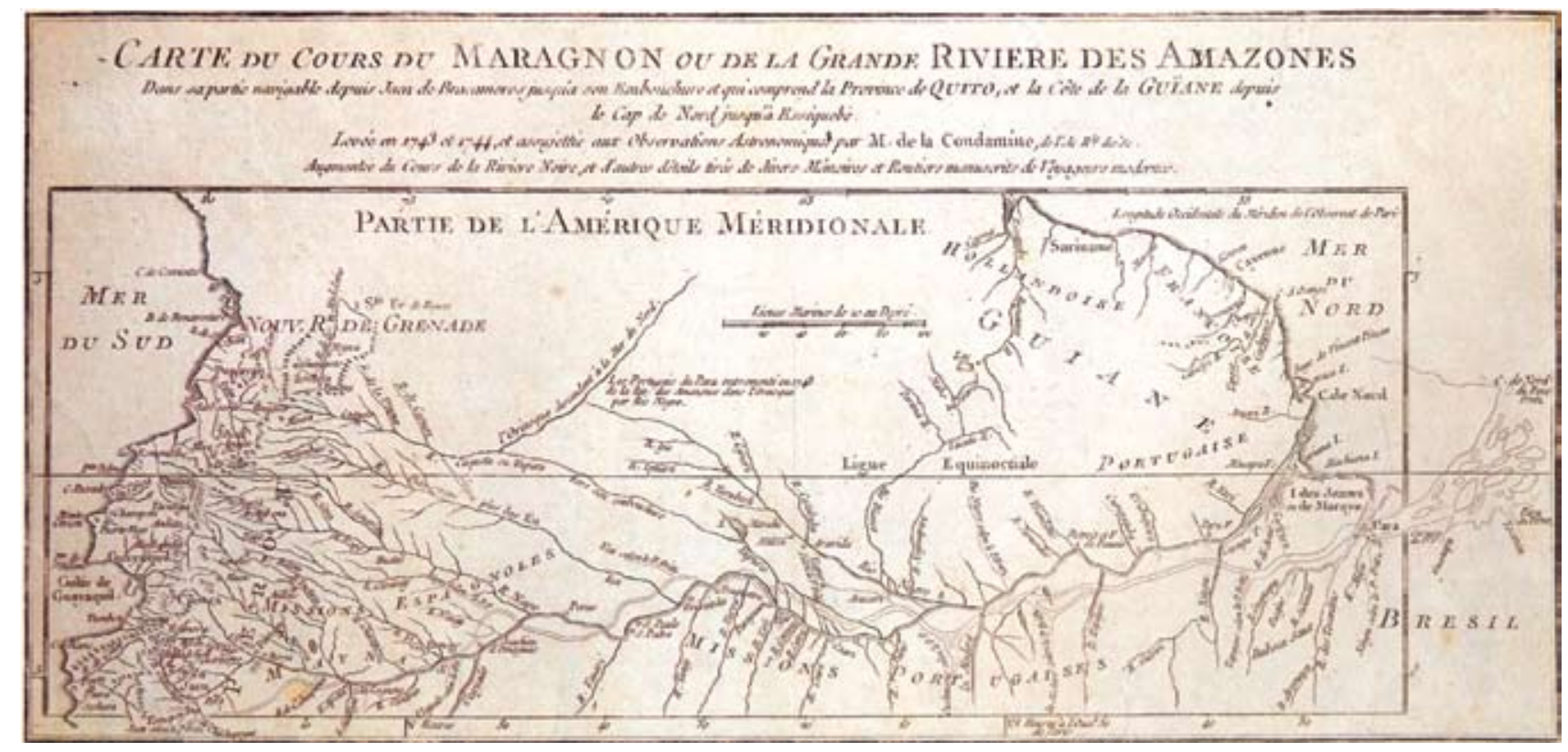

Figura 11 - Carte du cours du Maragnon, Charles Marie La Condamine (1745). Instituto de Estudos Brasileiros / USP (acervo depositado temporariamente pela Justiça Federall, São Paulo.

político ${ }^{33}$. Dá-se ainda uma boa conjugação deste esforço com a chegada dos geógrafos encarregados da demarcação das fronteiras que se seguiu ao novo Tratado de Santo Ildefonso (1777). Que, pela parte portuguesa, já trabalho de geógrafos saídos da Universidade de Coimbra, em grande parte reformada e renovada em 1772 para responder às necessidades do Brasil. Geógrafos exercitados em Portugal, para esse efeito, pelo cosmógrafo Dr. Miguel António de Ciera, italiano que trabalhara nas partidas do Sul do Brasil em 1753-175634. Um destes encarregados da demarcação, o Dr. Francisco José de Lacerda e Almeida, receberá ordem de, depois, passar a Moçambique e intentar a travessia da África ${ }^{35}$. Pela sua experiência, esta era uma boa escolha, como se vê pelas observações e por todos os mapas que esboçou do interior do leste africano.

Além do trabalho do Brasil, as demarcações na África foram uma escola do melhor que a cartografia portuguesa produziu. Por fins do século XVIII, António Pires da Silva Pontes Leme vai conseguir desenhar o mapa da Nova Lusitânia (circa 1798), trabalhando sobre oitenta e seis cartas parciais, o que fecha o século com a definição cartográfica do Brasil. Com latitudes e longitudes observadas, com indicações de geografia e econômica, etnográfica e política (Figura 14 (16. $^{36}$.

Ainda se faria muito mais nos anos que precedem a independência de 1822. Mas já será com a corte portuguesa no Brasil (1 808). Nisso Portugal para pouco ou nada é chamado. Mas foi decisivo na cartografia inicial da terra, no século XVI, e depois a sua participação na nova cartografia terrestre do Brasil, já científica, que se impõe para bem separar Portugal da Espanha. E, sobretudo, para bem se conhecer e dominar o território. E, assim, concretizar um país.
33. Sobre o assunto, consultar a publicação da Biblioteca Pública Municipal do Porto A Terra de Vera Cruz (2000); João Carlos Garcia (2002); e ainda Antônio Gilberto Costa (2004).

34. Ver Inácio Guerreiro (1997a).

35. Ver Quirino da Fonseca (1936); e A. Teixeira da Mota (1964).

36. Sobre o assunto, ver as publicações da Comissão Nacional para as Comemorações dos Descobrimentos, $A$ Nova Lusitânia (2001); e da Biblioteca Pública Municipal do Porto, A Terra de Vera Cruz (2000). 


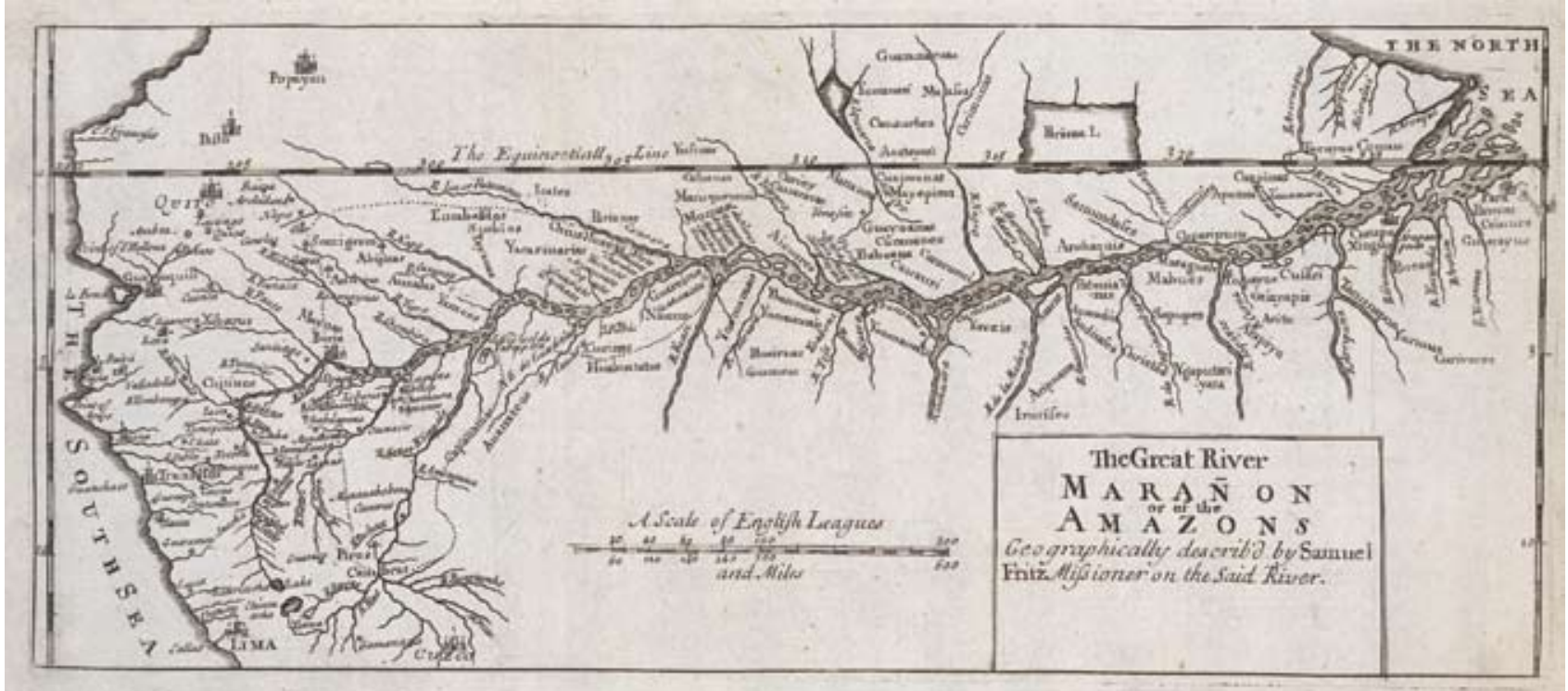

Figura 12 - [The great river Maranon or of the Amazon...], baseado no mapa do padre Samuel Fritz, c. 1690. Acervo do Instituto de Estudos Brasileiros / USP, São Paulo, temporariamente cedido pela Justiça Federal. 


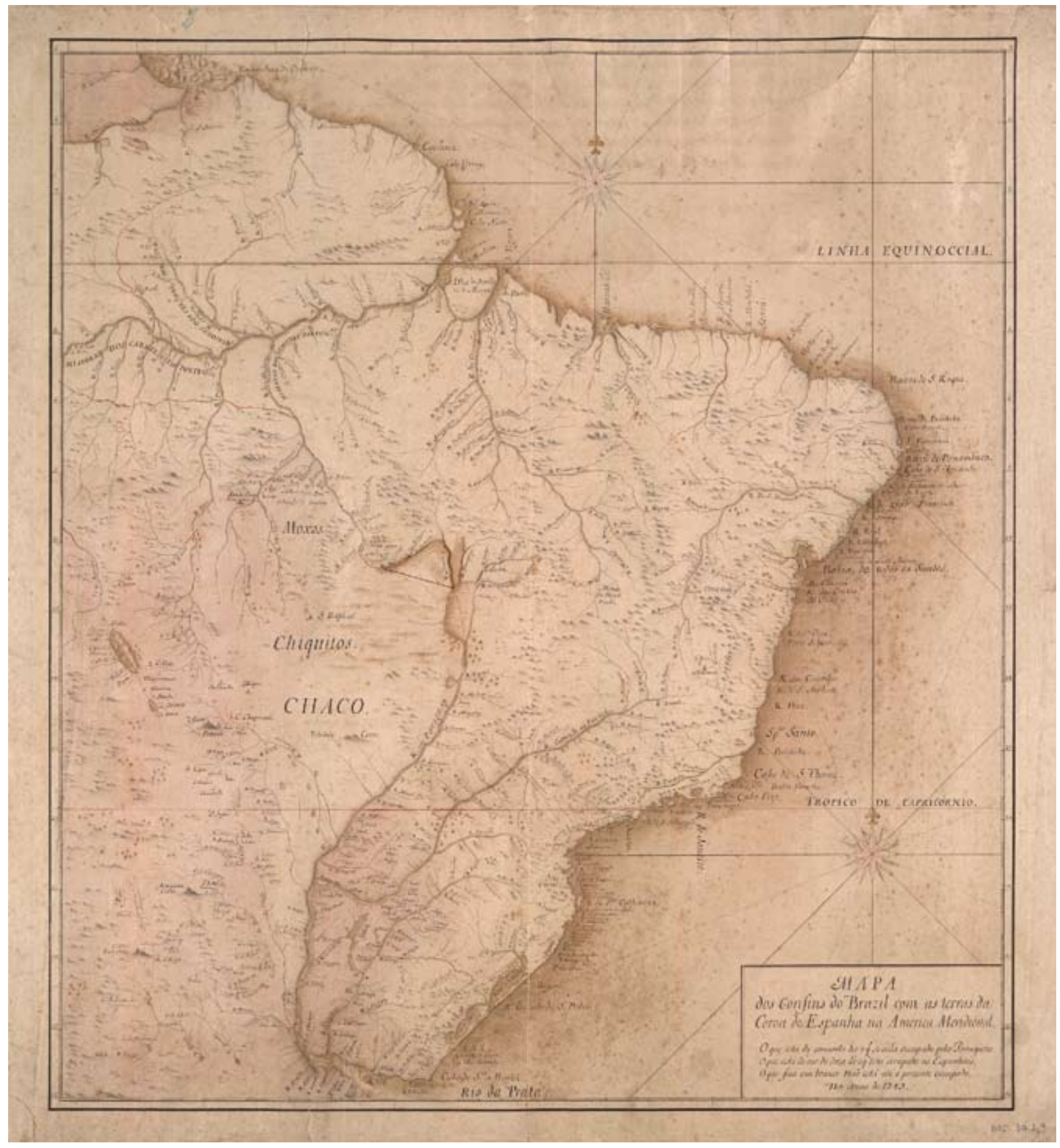

Figura 13 - Mapa das Cortes, 1749. Biblioteca Nacional, Rio de Janeiro. 


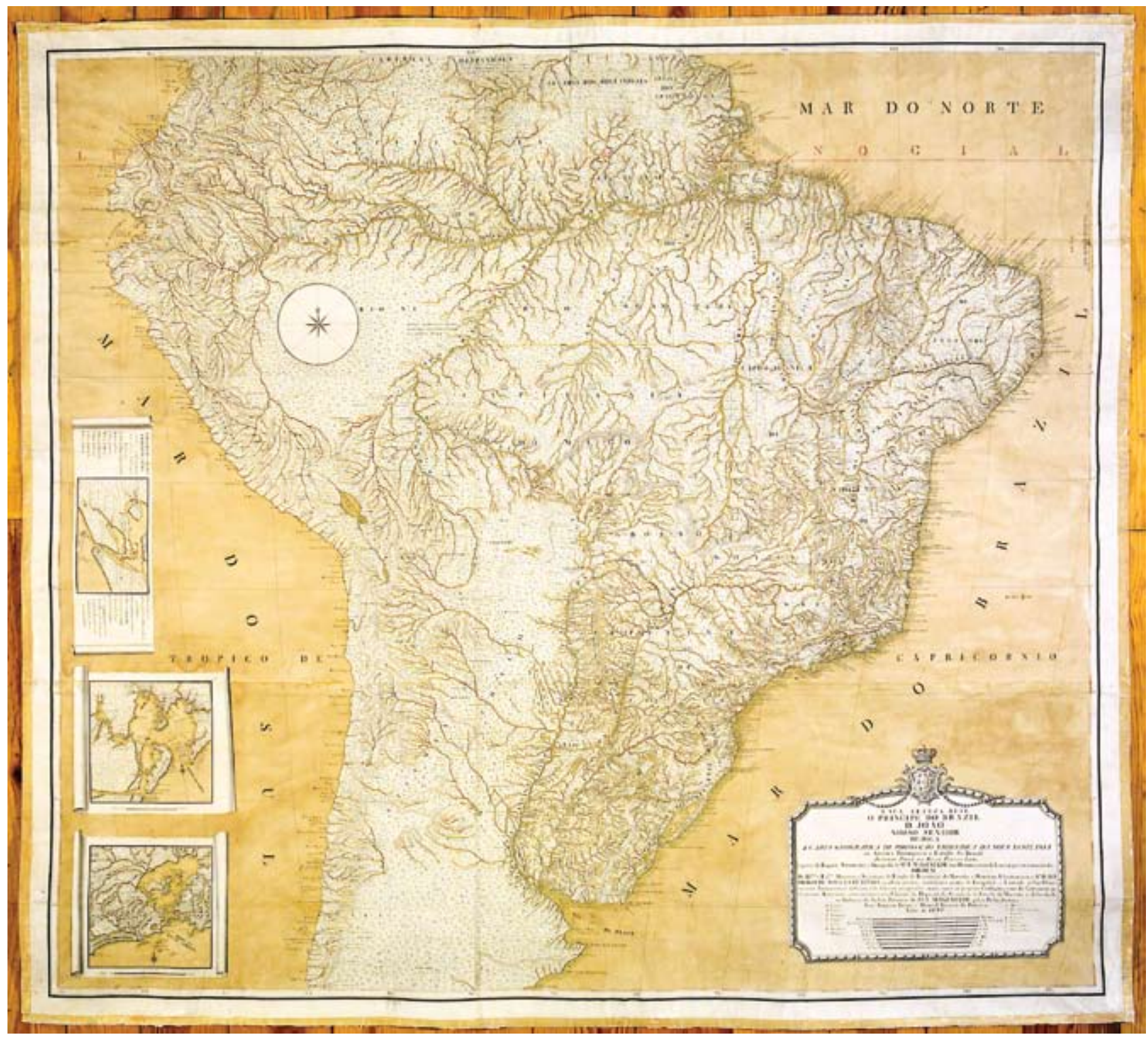

Figura 14 - Carta Geografica de Projeção Espherica da Nova Lusitania ou America portuguesa e Estado do Brazil. Antonio Pires da Silva Pontes Leme, 1797. Observatório Astronômico da Universidade de Coimbra, Coimbra. Fotografia de Nuno Fevereiro. 


\section{REFERÊNCIAS}

ALBUQUERQUE, Luís de; COTTON, Robert. Roteiro do Mar Roxo de dom João de Castro, 1540. Lisboa: Academia Portuguesa da História-Inapa; Londres: British Library, 1991.

ATLAS Miller. Barcelona: M. Moleiro, 2003.

CORTESÃO, Armando; MOTA, A. Teixeira da. Portugalice Monumenta Cartographica. Lisboa: Comissão Executiva das Comemorações do Quinto Centenário da Morte do Infante D. Henrique, 1960.

DESCRIPCÃO de todo o maritimo da terra S. Cruz chamado vulgarmente, o Brazil. Feito por João Teixeira cosmographo de Sua Magestade. Anno 1640. Ed. fac-sim. Lisboa: Arquivos Nacionais Torre do Tombo; ANA, 2000.

DESCRIPCÃ̃O de todo o maritimo da terra de Santa Crus chamado vulgarmente o Brasil, (ca. 1654). Ed. fac-sim. Coleção Brasiliana. Lisboa: Fundação Estudar, 2003.

GARCIA, João Carlos (coord.). A mais dilatada vista do Mundo. Inventário da colecção cartográfica da Casa da Ínsua. Lisboa: Comissão Nacional para as Comemorações dos Descobrimentos Portugueses, 2002.

LA CONDAMINE, Carlos Maria de. Relato abreviado de uma viagem pelo interior da América meridional. Trad. Aristides Ávila. São Paulo: Cultura, 1944.

MAGALHAES, Joaquim Romero; MIRANDA, Susana Münch. Os primeiros 14 documentos relativos à armada de Pedro Álvares Cabral. Lisboa: Comissão Nacional para as Comemorações dos Descobrimentos Portugueses, 1999.

TEIXEIRA, Dante Martins (Org.). A arte nos mapas na Casa Fiat de Cultura. Nova Lima: Casa Fiat de Cultura, 2008.

ZURARA, Gomes Eanes da. Crónica de Guiné. Porto: Civilização, 1973.

\section{Livros e Periódicos}

ALBERnAZ, João Teixeira. Descripção de todo o marítimo da Terra de S. Cruz chamado vulgarmente o Brazil. Lisboa: ANA; Aeroportos de Portugal; SA, 2000.

ALBUQUERQUE, Luís de. Realidades e mitos de Geografia Medieval. In: Estudos de História V. Coimbra: Biblioteca Geral da Universidade de Coimbra, 1977. p. 25-49.

ALBUQUERQUE, Luís de. Contribution des portugais à la découverte de l'Amérique du Nord. In: . Estudos de História V. Coimbra: Biblioteca Geral da Universidade de Coimbra, 1977.

ALEGRIA, Maria Fernanda Alegria; GARCIA, João Carlos. Etapas da evolução da cartografia portuguesa (séculos XV a XIX). In: LA CARTOGRAFIA de la Península Ibèrica y la seva extensió al continent amèrica. Barcelona: Institut Cartogràfic de Catalunya, 1991. 
ALEGRIA, Maria Fernanda. Representações do Brasil na produção dos cartógrafos Teixeira (c. 1586-1675). Mare Liberum, Lisboa, Comissão Nacional para as Comemorações dos Descobrimentos Portugueses, n. 10, p. 189-204, 1995.

ALEGRIA, Maria Fernanda; GARCIA, João Carlos; RELAÑO, Francesc. Cartografia e viagens. In: BETHENCOURT, Francisco; CHAUDHURI, Kirti. História da expansão portuguesa. Lisboa: Círculo de Leitores, 1998. p. 26-115.

ALMEIDA, André Ferrand de. A formação do espaço brasileiro e o projecto do Novo Atlas da América Portuguesa (1713-1748). Lisboa: Comissão Nacional para as Comemorações dos Descobrimentos Portugueses, 2001a.

ALMEIDA, André Ferrand de. Entre a Guerra e a Diplomacia: os conflitos luso-espanhóis e a cartografia da América do Sul (1702-1807). In: A Nova Lusitânia. Imagens cartográficas do Brasil nas colecções da Biblioteca Nacional (1700-1822), Lisboa: Comissão Nacional para as Comemorações dos Descobrimentos Portugueses, 2001b.

A NOVA LUSITÂNIA. Imagens Cartográficas do Brasil nas Colecções da Biblioteca Nacional (1700-1822). Lisboa: Comissão Nacional para Comemoração dos Descobrimentos Portugueses, 2001.

A TERRA de Vera Cruz. Viagens, descrições e mapas do século XVIII, Porto: Biblioteca Pública Municipal do Porto, 2000.

BROC, Numa. La Géographie des philosophes. Géographes et voyageurs français au XVIII siècle. Paris: Ophrys, 1975.

CARACI, Laria Luzzana. A expansão do Mundo nos planisférios da Biblioteca Estense Universitária de Modena. In: VENTURA, Maria da Graça Mateus; MATOS, Luís Jorge Semedo de (Org.). As novidades do Mundo. Conhecimento e representação na Época Moderna. Lisboa: Colibri, 2003.

CORTESÃO, Jaime. Introdução à bistória das bandeiras. Lisboa: Portugália, 1964.

CORTESÃO, Jaime. História do Brasil nos velbos mapas. Rio de Janeiro: Instituto Rio-Branco, 1965-1971.

CORTESÃO, Armando. History of the Portuguese Cartography. Coimbra: Junta de Investigações Científicas do Ultramar, 1969-1971.

CORTESÃO, Armando. Atlas e história da cartografia. In: Esparsos II. Coimbra: Biblioteca Geral da Universidade de Coimbra, 1975.

CORTESÃO, Armando. A Suma Oriental de Tomé Pires e o Livro de Francisco Rodrigues. Coimbra: Biblioteca Geral da Universidade de Coimbra, 1978.

CORTESÃO, Jaime. Alexandre de Gusmão e o Tratado de Madrid. Lisboa: Horizonte, 1983-1984.

COSTA, A. Fontoura da. A marinharia dos descobrimentos. Lisboa: Agência Geral das Colónias, 1939.

COSTA, Antônio Gilberto (Org.). Cartografia da conquista do território das Minas. Belo Horizonte: Editora da UFMG; Lisboa: Kapa, 2004.

DAVEAU, Suzanne. La geographie dans les "roteiros" portugais des $\mathrm{XV}^{\mathrm{e}}$ et $\mathrm{XVI}{ }^{\mathrm{e}}$ siècles. Mare Liberum, Lisboa, Comissão Nacional para as Comemorações dos Descobrimentos Portugueses, $\mathrm{n}$. 3, pp.161-181, 1991. 
FERNANDES, Fernando Lourenço. O planisfério de Cantino e o Brasil. Uma introdução à cartologia política dos descobrimentos e o Atlântico Sul. Lisboa: Academia de Marinha, 2003.

FERREIRA, Mário Clemente. Uma ideia de Brasil num mapa inédito de 1746. Oceanos, Lisboa, omissão Nacional para Comemoração dos Descobrimentos Portugueses, n. 43, pp. 184-195, 2000 .

FERREIRA, Mário Clemente. O Tratado de Madrid e o Brasil meridional. Os trabalhos demarcadores das partidas do Sul e a sua produção cartográfica (1749-1761), Lisboa: Comissão Nacional para Comemoração dos Descobrimentos Portugueses, 2001.

FERREIRA, Mário Clemente. O Mapa das Cortes e o Tratado de Madrid: a cartografia a serviço da diplomacia. Varia Historia, Belo Horizonte, Universidade Federal de Minas Gerais, v. 23, n. 37, pp.51-69, 2007.

FONSECA, Quirino da. Um drama no sertão. Tentativa da travessia de Africa em 1798. Famalicão: Minerva, 1936.

GARCIA, João Carlos (Org.). A mais dilatada vista do Mundo. Inventário da colecção cartográfica da Casa da Ínsua, Lisboa, Comissão Nacional para Comemoração dos Descobrimentos Portugueses, 2002.

GODINHO,Vitorino Magalhães. Documentos sôbre a expansão portuguesa, v.1. Lisboa: Gleba, 1944.

GUEDES, Max Justo. Aspectos náuticos da expedição de Pedro Teixeira (1636-1639). In: DOMINGUES, Francisco Contente; BARRETO, Luís Filipe. A abertura do Mundo. Estudos de História dos Descobrimentos Europeus. Lisboa: Presença, 1987.

GUEDES, Max Justo. A cartografia portuguesa antiga. In: TESOUROS da Cartografia Portuguesa. Lisboa: Inapa; Comissão Nacional para as Comemorações dos Descobrimentos Portugueses, $1997 a$.

GUEDES, Max Justo. A cartografia da delimitação das fronteiras do Brasil no século XVIII. In: CARTOGRAFIA e diplomacia no Brasil do século XVIII. Lisboa: Comissão Nacional para as Comemorações dos Descobrimentos Portugueses, 1997b.

GUEDES, Max Justo. A cartografia Holandesa no Brasil. In: HERKENHOFF, Paulo. O Brasil e os Holandeses 1630-1654. Rio de Janeiro: Sextante Artes, 1999. [pp 64-85]

GUERREIRO, Inácio. A carta náutica de Jorge de Aguiar de 1492. Lisboa: Academia de Marinha, 1992.

GUERREIRO, Inácio. Ciência e cartografia: a imagem do Mundo físico em Portugal em finais do séc. XV. In: SOCIEDAD V CENTENARIO DEL TRATADO DE TORDESILLAS (Org.). Congreso Internacional de Historia el Tratado de Tordesillas. El Tratado de Tordesillas y su época 2. Madrid: SVCTT; Comissão Nacional para as Comemorações dos Descobrimentos Portugueses, 1995.

GUERREIRO, Inácio. As demarcações segundo o Tratado de Santo Ildefonso de 1777. In: CARTOGRAFIA e diplomacia no Brasil do século XVIII. Lisboa: Comissão Nacional para Comemoração dos Descobrimentos Portugueses, 1997a.

GUERREIRO, Inácio. Tábuas, cartas e roteiros. In: PEDROSA, Fernando Gomes (Org.). História da Marinha Portuguesa. Navios, marinheiros e arte de navegar, 1139-1499. Lisboa: Academia de Marinha, 1997b. 
LEITE, Duarte. História dos descobrimentos. Colectânea de esparsos. Lisboa: Cosmos, 1959-1960.

MAGALHÃES, Joaquim Romero; MIRANDA, Susana Münch. Os primeiros 14 documentos relativos à armada de Pedro Álvares Cabral. Lisboa: Comissão Nacional para as Comemorações dos Descobrimentos Portugueses, 1999.

MARQUES, Alfredo Pinheiro. Origem e desenvolvimento da cartografia portuguesa na época dos descobrimentos. Lisboa: Imprensa Nacional; Casa da Moeda, 1987.

MENDES, H. Gabriel. Lucas Jansz. Waghenaer e o conbecimento das costas de Portugal no século XVI. Coimbra: Junta de Investigações do Ultramar, 1969.

MOTA, A. Teixeira da. A viagem de Bartolomeu Dias e as concepções geopolíticas de D. João II. Boletim da Sociedade de Geografia de Lisboa, Lisboa, p.297-322, out.-dez. 1958.

MOTA, A. Teixeira da. A cartografia antiga da Africa central e a travessia entre Angola $e$ Moçambique, 1500-1860. Lourenço Marques: Sociedade de Estudos de Moçambique, 1964.

MOTA, A. Teixeira da. Reflexos do Tratado de Tordesilhas na cartografia náutica do século XVI. Revista da Universidade de Coimbra, Coimbra, v. 23, 1973.

MOTA, A. Teixeira da. A África no Planisfério de Cantino. Revista da Universidade de Coimbra: Homenagem ao Doutor Armando Cortesão (1 ${ }^{\mathrm{a}}$ parte), Coimbra, v. 26, 1978.

PADRON, Francisco Morales. Historia del descubrimiento y conquista de América. 5. ed. Madrid: Gredos, 1990.

RANDLES, W. G. L. Science et cartographie. L'image du monde physique à la fin du XV siècle. In: SOCIEDAD V CENTENARIO DEL TRATADO DE TORDESILLAS (Org.). Congreso Internacional de Historia el Tratado de Tordesillas. El Tratado de Tordesillas y su época tomo: II. Madrid: SVCTT; Comissão Nacional para as Comemorações dos Descobrimentos Portugueses, 1995.

ROTEIRO de todos os sinais, conhecimentos, fundos, baixos, alturas e derrotas que há na costa do Brasil, desd'o Cabo de Santo Agostinho até o Estreito de Fernão de Magalhães. Boletim Internacional de Bibliografia Luso-Brasileira, Lisboa, Fundação Calouste Gulbenkian, v. 6, n. 2 , pp. 201-397, abr.-jun. 1965.

SIQUEIRA, Bueno Beatriz P. "Desenhar" (projetar) em Portugal e Brasil nos séculos XVI-XVIII. Revista de Estudos sobre Urbanismo, Arquitetura e Preservação, São Paulo, Faculdade de Arquitetura e Urbanismo-Universidade de São Paulo, p. 1-45, jul.-dez. 2002.

VERLINDEN, Charles. Quand commença la cartographie portugaise? Lisboa: Junta de Investigações Científicas do Ultramar, 1979.

WASHBURN, Wilcom E. Representation of unknown lands in XIV-, XV-and XVI-Century Cartography. Coimbra: Junta de Investigações do Ultramar, 1969.

Artigo apresentado em 8/2008. Aprovado em 12/2008. 